\title{
Environmental Sustainability Framework for Plastic Waste Management - A Case Study in Bubble Tea Streets of Ss15, Subang Jaya
}

\section{Chie Jian Lee}

Monash University Malaysia

\section{Lam Chang}

Monash University Malaysia

Jully Tan ( $\nabla$ tan.jully@monash.edu )

Monash University Malaysia https://orcid.org/0000-0002-2767-4414

\section{Research Article}

Keywords: Bubble tea industry, plastic waste, sanitary landfill, waste to energy incineration, life cycle assessment, sustainability framework

Posted Date: March 17th, 2021

DOI: https://doi.org/10.21203/rs.3.rs-157966/v1

License: (c) (i) This work is licensed under a Creative Commons Attribution 4.0 International License. Read Full License 


\section{Environmental sustainability framework for plastic waste management - A case study in Bubble Tea Streets of} SS15, Subang Jaya

First Author: Chie Jian Lee (CJ) Institute: School of Engineering, Monash University Malaysia, Jalan Lagoon Selatan, 47500, Bandar Sunway, Selangor. Email: leechiejian@gmail.com

Second Author: Lam Chang (LC)

Institute: School of Engineering, Monash University Malaysia, Jalan Lagoon Selatan, 47500, Bandar Sunway, Selangor. Email: changlam2008@hotmail.com

Corresponding Author: Jully Tan (JT) Institute: School of Engineering, Monash University Malaysia, Jalan Lagoon Selatan, 47500, Bandar Sunway, Selangor. Email: tan.jully@monash.edu 
Economic growth and rapid industrialisation have led to enormous increase in municipal solid waste (MSW) in the urban areas. Lack of waste management alternatives and ineffective waste policy implementation are the major challenges for government to materialise a sustainable solid waste management framework, especially for plastic waste. Booming bubble tea industry has aggravated the situation by generating more plastic waste which are either non-recyclable or rejected by recycling facilities as they have low or no economic values. Hence, this study aims to evaluate the overall environmental performance of existing and alternative waste management technologies that are available in Malaysia based on net greenhouse gas (GHG) emission in terms of carbon dioxide equivalent per tonne of plastic waste that are analysed through life cycle assessment (LCA) methodology. Waste management technology with better environmental performance is taken into account in environmental sustainability framework development for plastic waste management based on the case study in Bubble Tea Streets of Subang Jaya. Two scenarios of waste management technologies are considered: (A) sanitary landfill; (B) waste to energy (WTE) incineration. Results showed that Scenario B (WTE incineration) is more environmentally preferable as it has a negative net GHG emission of $573.80 \mathrm{~kg} \mathrm{CO}$-eq as compared to GHG emission of existing sanitary landfill $\left(566.15 \mathrm{~kg} \mathrm{CO}_{2}\right.$ eq.). Negative net GHG emission in WTE incineration is mainly due to higher GHG saving achieved through cleaner electricity generation as compared to conventional power production. This proposed alternative technology has the potential to reduce the dependence on landfills and is served as the basis of framework development. The environmental sustainability framework for plastic waste management can be baseline for the local authorities or policy makers for other plastic waste generation hotspots other than bubble tea industry to improve plastic waste management via WTE incineration.

Keywords: Bubble tea industry, plastic waste, sanitary landfill, waste to energy incineration, life cycle assessment, sustainability framework

\section{List of symbols}

$\Phi_{P}$ : Total electricity consumption for production of bubble milk tea (kWh)

$W_{i}$ : Power rating of each electrical appliance $(\mathrm{kW})$

$H R_{\text {Average }}$ : Average operating hours (h)

$N_{\text {Shops }}:$ Number of bubble tea shops 
$\mathrm{EF}_{\text {mix }}$ : Emission factor of $\mathrm{CO}_{2}$ based on electricity generation mix in Malaysia $(\mathrm{kg} \mathrm{CO}-$-eq/kWh)

$E_{\mathrm{CO}_{2}, \mathrm{~T}}: \mathrm{CO}_{2}$ emission from transportation $\left(\mathrm{kg} \mathrm{CO}_{2}\right.$-eq)

$60 N C V_{\text {diesel }}$ : Net calorific value of diesel $(\mathrm{MJ} / \mathrm{kg})$

$61 \mathrm{EF}_{\text {diesel }}$ : Emission factor of $\mathrm{CO}_{2}$ from diesel combustion $\left(\mathrm{kg} \mathrm{CO}_{2}\right.$-eq $\left./ \mathrm{TJ}\right)$

62

$E_{\mathrm{CO}_{2}, \mathrm{~L}}: \mathrm{CO}_{2}$ emission from landfill ( $\left.\mathrm{kg} \mathrm{CO}_{2}-\mathrm{eq}\right)$

PW: Plastic waste $(\mathrm{t})$

$E F_{\mathrm{CO}_{2}, \mathrm{~L}}$ : Emission factor of $\mathrm{CO}_{2}$ from landfill $\left(\mathrm{kg} \mathrm{CO}_{2}-\mathrm{eq} / \mathrm{t}\right)$

$\Phi_{L}$ : Electricity consumption for compacting the waste in landfill ( $\left.\mathrm{kWh}\right)$

$\rho_{\mathrm{CO}_{2}}:$ Density of $\mathrm{CO}_{2}\left(\mathrm{~kg} / \mathrm{m}^{3}\right)$

$\rho_{\mathrm{CH}_{4}}$ : Density of $\mathrm{CH}_{4}\left(\mathrm{~kg} / \mathrm{m}^{3}\right)$

$\mathrm{NCV}_{\mathrm{CH}_{4}}$ : Net calorific value of $\mathrm{CH}_{4}\left(\mathrm{kWh} / \mathrm{m}^{3}\right)$

69 Q $\mathrm{CH}_{4}$ : Volume of $\mathrm{CH}_{4}$ in landfill gas $\left(\mathrm{m}^{3}\right)$

$\sigma$ : Capturing efficiency of LGRS

$\eta_{L}$ : Electrical energy production efficiency of LGRS

$E_{\mathrm{CO}_{2}, \mathrm{SL}}$ : GHG saving from electricity generation from LGRS ( $\mathrm{kg} \mathrm{CO}_{2}$-eq)

$E_{C_{H_{4}}}$ : Emission factor of $\mathrm{CO}_{2}$ from $\mathrm{CH}_{4}$ combustion $\left(\mathrm{kg} \mathrm{CO}_{2}\right.$-eq $\left./ \mathrm{TJ}\right)$

$E_{\mathrm{CO}_{2}, \mathrm{I}}$ : Emission of $\mathrm{CO}_{2}$ from incineration $\left(\mathrm{kg} \mathrm{CO}_{2}\right.$-eq)

Dm: Dry matter content of plastic waste

CF: Fraction of carbon in dry matter

FCF: Fraction of fossil carbon

OF: Oxidation factor (fraction)

44/12: Conversion factor from $\mathrm{C}$ to $\mathrm{CO}_{2}$

$\Phi_{I}$ : Electricity consumption for start-up of incinerator

Fuel $_{I}$ : Natural gas consumption for start-up of incinerator (MJ)

$E F_{\text {gas }}$ : Emission factor of $\mathrm{CO}_{2}$ from natural gas combustion $\left(\mathrm{kg} \mathrm{CO}_{2}\right.$-eq $\left./ \mathrm{TJ}\right)$

$83 E_{N_{2} O, I}$ : Emission of $\mathrm{N}_{2} \mathrm{O}$ from incineration $\left(\mathrm{kg} \mathrm{N}_{2} \mathrm{O}\right)$

$E F_{N_{2} O, I}$ : Emission factor of $\mathrm{N}_{2} \mathrm{O}$ from incineration $\left(\mathrm{kg} \mathrm{N}_{2} \mathrm{O} / \mathrm{t}\right)$

$N C V_{P P}$ : Net calorific value of PP plastic $(\mathrm{kWh} / \mathrm{kg})$

$\eta_{I}$ : Electrical energy production efficiency of incineration 


\section{Introduction}

Kaza et al. (2018) stated that 242 million tonne of global plastic waste has been generated, which was $12 \%$ of global municipal solid waste in accordance to the statistics from The World Bank in year 2016. $91 \%$ of the plastic waste is not recyclable. This plastic waste will lead to global warming and climate change as they are either burned in open environment or being disposed into landfills, and only $12 \%$ of the plastic waste has undergone proper treatment such as incineration. Packaging industry is the primary source of plastic waste generation and approximately 141 million tonne of global plastic waste has been generated by this industry in year 2015. This is because packaging plastics products from this industry have a very short life cycle of not more than six months. Therefore, this industry is responsible for two-thirds of the global plastic waste generation (Geyer et al., 2017).

Recently, bubble tea industry has created a hype to the whole world with their signature brown sugar milk bubble tea and since then, bubble tea has become an iconic drink in which every youngster is craving for it. Besides, bubble tea shops can be found almost everywhere around the commercial areas due to the hype, especially at the famous Bubble Tea Streets in Subang Jaya, Malaysia. It is reported approximately 74 brands of bubble tea vendors in Malaysia (Tan, 2019). High demand of bubble tea has led to significant increase in production of plastic waste. However, landfill is the only existing waste disposal method for plastic waste in Malaysia and plastic waste takes longer time to degrade in landfill as compared to other types of municipal solid waste (MSW) in which the high rate of plastic waste generation from bubble tea industry will speed up the filling up rate of landfill in the long run. As a result, the authorities have been struggling to materialise a sustainable waste management framework to deal with increase in plastic waste issue.

According to current Solid Waste Management Lab Report produced by Ministry of Housing and Local Government Malaysia (KPKT) (2015), the government had set a target to divert $40 \%$ waste from landfills by year 2020. However, the booming of bubble tea industry in year 2019 has aggravated the situation making the target harder to achieve. This is because bubble tea vendors tend to utilise petroleum based single-use plastics with added additives as packaging materials in which are either non-recyclable or rejected by recycling facilities as they have low or no economic values. On top of that, ineffective waste policy implementation and lack of recycling awareness among Malaysian have led to low rate of plastic recycling (Alias et al., 2018). Furthermore, first waste to energy (WTE) incinerator in Malaysia is expected to begin 
its operation in 2021 (Aziz, 2020). As a result, plastic waste from bubble tea industry will still ended up in the landfills. Therefore, all these factors have hastened the government's plan to begin operation of WTE incinerator as soon as possible to tackle the increasing plastic waste issue.

It is also well noting that only 10 out of the 166 landfills in Malaysia are sanitary landfills with landfill gas recovery system (LGRS) which lead to serious global warming issue (KPKT, 2015). As Malaysia has yet to begin operation of any WTE incinerator and therefore, the environmental performance of this alternative technology is not known. As a result, GHG emission from sanitary landfill and WTE incineration cannot be compared which hinder the sustainable plastic waste management framework development for government to tackle increasing rate of plastic waste generation.

Therefore, this study aims to evaluate the overall environmental performance of existing sanitary landfill and alternative WTE incineration via life cycle assessment (LCA) with Bubble Tea Streets of Subang Jaya in Malaysia as case study. An environmental sustainability framework for plastic waste management based on case study is developed which highlights the engagement between government, waste contractors, bubble tea vendors and public to ensure a long term application of the proposed framework in managing the municipal plastic waste efficiently.

\section{Literature Review}

Sanitary landfill is a well-designed system that has geomembrane which is made of high density polyethylene (HDPE) as foundation, drainage system to channel leachate accumulated at the bottom of landfill to leachate treatment plant and LGRS to capture methane $\left(\mathrm{CH}_{4}\right)$. The dominant types of GHG emission from landfilling are $\mathrm{CH}_{4}$ and $\mathrm{CO}_{2}$. Landfilling is the major source of $\mathrm{CH}_{4}$ emission which account for $53 \%$ of $\mathrm{CH}_{4}$ emission in Malaysia and $\mathrm{CH}_{4}$ emission from non-sanitary landfills are much greater than the emission from sanitary landfills. It is predicted that 370,000 tonne of $\mathrm{CH}_{4}$ is to be produced in year 2020, which is equivalent to 9.25 million tonne $\mathrm{CO}_{2}$-eq (Yong et al., 2019). This amount of greenhouse $\mathrm{CH}_{4}$ is 25 times more potent than $\mathrm{CO}_{2}$ in warming the earth. Although sanitary landfills can reduce these negative environmental impacts as compared to non-sanitary landfills, establishing a new sanitary landfill to trap $\mathrm{CH}_{4}$ can be a challenging task for authorities due to land scarcity, high land cost 
around urban area and negative perception from residents/communities who are living near the landfills.

Incineration is a thermal waste treatment technology that burn waste under high temperature into ash, heat and flue gas. The dominant types of GHG emission from incineration process are $\mathrm{CO}_{2}$ and nitrous oxide $\left(\mathrm{N}_{2} \mathrm{O}\right)$. There are two types of incineration i.e. incineration with and without energy recovery, with the latter one does not harness useful energy from flue gas to generate electricity. Incineration is the most common thermal treatment of plastic waste as compared to pyrolysis and gasification. There are several major challenges for Malaysia to establish WTE incinerators. Firstly, the moisture content in the municipal solid waste in Malaysia is approximately $45 \%$ will lead to ineffective incineration process. However, nonorganic waste such as plastic waste with very low moisture content and high calorific value making it suitable for thermal treatment (Yong et al., 2019). Secondly, high capital and maintenance costs hinder developing countries like Malaysia to invest money on establishing more WTE incinerators. Nevertheless, incineration saves cost in the long run as it reduces volume of waste by converting them into energy.

Malaysia has installed her first large scale WTE incinerator in Negeri Sembilan. This incinerator is scheduled to operate in 2021 which can help to divert MSW including plastic waste from landfills (Aziz, 2020). Besides, the most common type of WTE incineration is moving grate incinerator which has numerous benefits such as it does not require waste sorting or pre-treatment of waste, accommodate large waste volume and having the ability to handle all types of MSW as well as able to achieve complete combustion to maximise the extraction of heat energy from waste for electricity generation or district heating (Lew, 2020).

Recycling plastic waste has its challenges as majority of plastic products fall under the category of plastic grade four to seven which are rarely to be recycled or non-recyclable (Kaza et al., 2018). Plastic of all grades usually contain additives, adding difficulties in recycling. Moreover, plastic products such as packaging plastics often consist of more than a single type of plastic grade, which are usually termed as mixed plastics, adding more difficulties in sorting and recycling these plastics. Besides this, production of biodegradable plastics is very low, which is only one percent of global plastic production. Plastic products from grade one and two which are widely recycled can only be recycled once or twice and recycling processes often produce plastic products of lower quality and these products will eventually ended up either in the 
landfills or incinerators (Ritchie and Roser, 2018). Thus, it is more economical to incinerate plastic waste if these plastics are too difficult to be sorted and recycled. Furthermore, recycling plastic is difficult as compared to recycling metals and glasses. Therefore, many developed nations get rid of their plastic waste in a cheap way by exporting them to developing nations such as China and Malaysia for recycling purposes (Wang et al., 2019). However, many of these discarded plastics are not recyclable and this plastic waste will eventually ended up in landfills or incinerators in which both waste management technologies can create electricity from the plastic waste. Although recycling plastic waste is a better option in accordance to waste hierarchy, but WTE technology is compatible or even does better than recycling in circular economy from overall sustainability point of view as it recovers both energy and materials from non-recyclable waste which keeps the environmental and humans free from toxic substances (Van Caneghem et al., 2019).

New Zealand (NZ), a country having a very similar waste composition is keen to explore sustainable waste treatment alternative such as WTE technologies to divert MSW from landfills. Three WTE thermal treatment technologies were studied and compared based on contexts of NZ, which are incineration, pyrolysis and gasification. The result of the literature suggested that incineration is still the most suitable WTE technology to replace landfill due to its ability to largely reduce volume of waste, matured technology, ability to handle variant of MSW and suitable for large scale application to deal with increasing MSW in the long run. Besides, pyrolysis and gasification create more side products that require further downstream treatment processes which will lead to greater emission whereas bottom ash from incineration can be used as construction material. Moreover, modern WTE incinerators have an electrical energy production efficiency of $30 \%$ which is higher than the efficiency of gasification and pyrolysis of $27 \%$ and $25 \%$ respectively (Perrot and Subiantoro, 2018).

According to United States Environmental Protection Agency, USEPA (2016), incineration of MSW generates lesser GHGs than coal, oil and natural gas as shown in Table 1. This is a good news for Malaysian as $86 \%$ of current power generation in Malaysia are from non-renewable resources as shown in Fig.1 (Abdullah et al., 2019). Therefore, WTE incineration is an environmental friendly option to reduce dependence on fossil fuels, divert $40 \%$ of MSW, especially plastic waste from landfills and reduce effect of global warming by reducing GHG emission from burning of fossil fuels and landfilling. 

(USEPA, 2016).

\begin{tabular}{cc}
\hline Fuel & GHG emission (kg CO2 per MWh) \\
\hline MSW & 461 \\
Coal & 1020 \\
Oil & 758 \\
Natural Gas & 515 \\
\hline
\end{tabular}

Table 2 Power generation sources in Malaysia in 2016 (Abdullah et al., 2019).

\begin{tabular}{cc}
\hline Power Generation Sources & $\begin{array}{c}\text { Contribution to Energy Production of } \\
\text { Malaysia in Percentage (\%) }\end{array}$ \\
\hline Natural Gas & 43.5 \\
Coal & 42.5 \\
Hydropower & 13.0 \\
Oil & 0.3 \\
Diesel & 0.3 \\
Others & 0.4 \\
\hline
\end{tabular}

217 Global temperature has increased by more than $1{ }^{\circ} \mathrm{C}$ since pre-industrial times. This is mainly 218 caused by human activities that generate huge amount of GHGs in to the atmosphere. 219 Approximately 36 billion t of $\mathrm{CO}_{2}$ emitted globally every year and this amount is too huge that 220 it is needed to be reduced in order to reduce the impacts of climate change (Ritchie and Roser, 2017). Therefore, this study focuses on reducing GHG emission from the waste sector, especially for plastic waste by comparing overall environmental performance of existing sanitary landfill and alternative WTE incineration to determine which waste disposal/management technology is environmentally more suitable in handling plastic waste. The 2006 Intergovernmental Panel on Climate Change (IPCC) Guidelines for National Greenhouse Gas Inventories is the guideline recognised by worldwide and widely used in literature studies which provide methodologies to determine for three major types of GHG emission, namely $\mathrm{CO}_{2}, \mathrm{CH}_{4}$ and $\mathrm{N}_{2} \mathrm{O}$ from man-made activities such as waste management (Eggleston et al., 2006).

LCA is the methodology used in environmental sustainability evaluation to quantify the environmental impacts of different waste management technologies based on energy and resource inputs as well as the GHG emission and saving. LCA has four main components, which are goal and scope definition, inventory analysis, impact assessment and interpretation 
234 of result (Arvanitoyannis, 2008). LCA enables ones to perform different analysis based on 235 defined system boundary, inventory analysis and made assumptions (Tan et al., 2017).

\section{$236 \quad 3 . \quad$ Methodology}

237 This study focuses on utilisation of plastic cups and downstream process which mainly on 238 management of plastic waste from Bubble Tea Streets in Subang Jaya, Malaysia. It is important 239 to collect information such as (i) plastic cup grades, (ii) number of bubble tea shops and (iii) 240 type of electrical appliances used in these shops via site visit and walk-in interview with bubble tea vendors as these primary data are the important inputs for this LCA study.

\section{Goal and Scope Definition}

243 The goal of this LCA study is to evaluate environmental impacts of the existing and alternative 244 waste management scenarios (Scenario A: Sanitary Landfill and Scenario B: WTE Incineration) 245 by quantifying GHG emission of the plastic waste from bubble milk tea industry. These two waste management technologies are to be compared for identification of better scenario with lowest net GHG emission. The functional unit is served to be the basis of comparison in the LCA system and the functional unit for this study is one tonne of plastic waste from Bubble Tea Streets of Subang Jaya. This LCA is a gate to grave system. The system boundary of LCA includes four phases, which are: production of bubble milk tea, consumption of bubble milk tea contained in plastic cups, plastic waste collection and transportation and disposal of plastic waste. Fig.1 and Fig. 2 show the system boundaries of Scenario A and B respectively.

Please take note that plastic cup waste is termed as plastic waste in this study. There is no consumption of energy and emission during milk tea consumption by customer and material (plastic cup) is similar as input and output. Therefore, no inventory data analysis and impact assessment are conducted for this particular phase. 


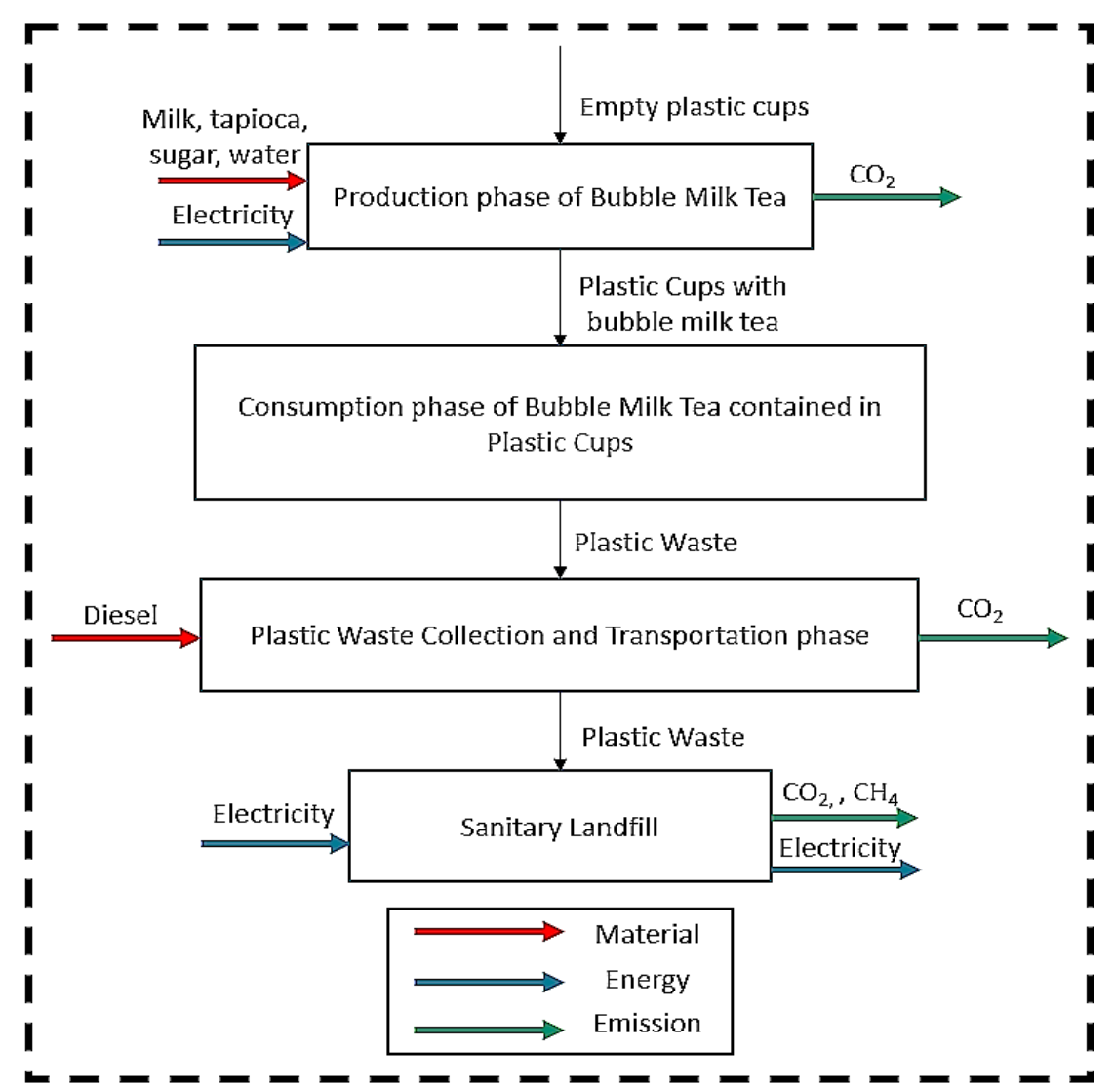

Fig.1 System boundary of existing plastic waste management for Scenario A

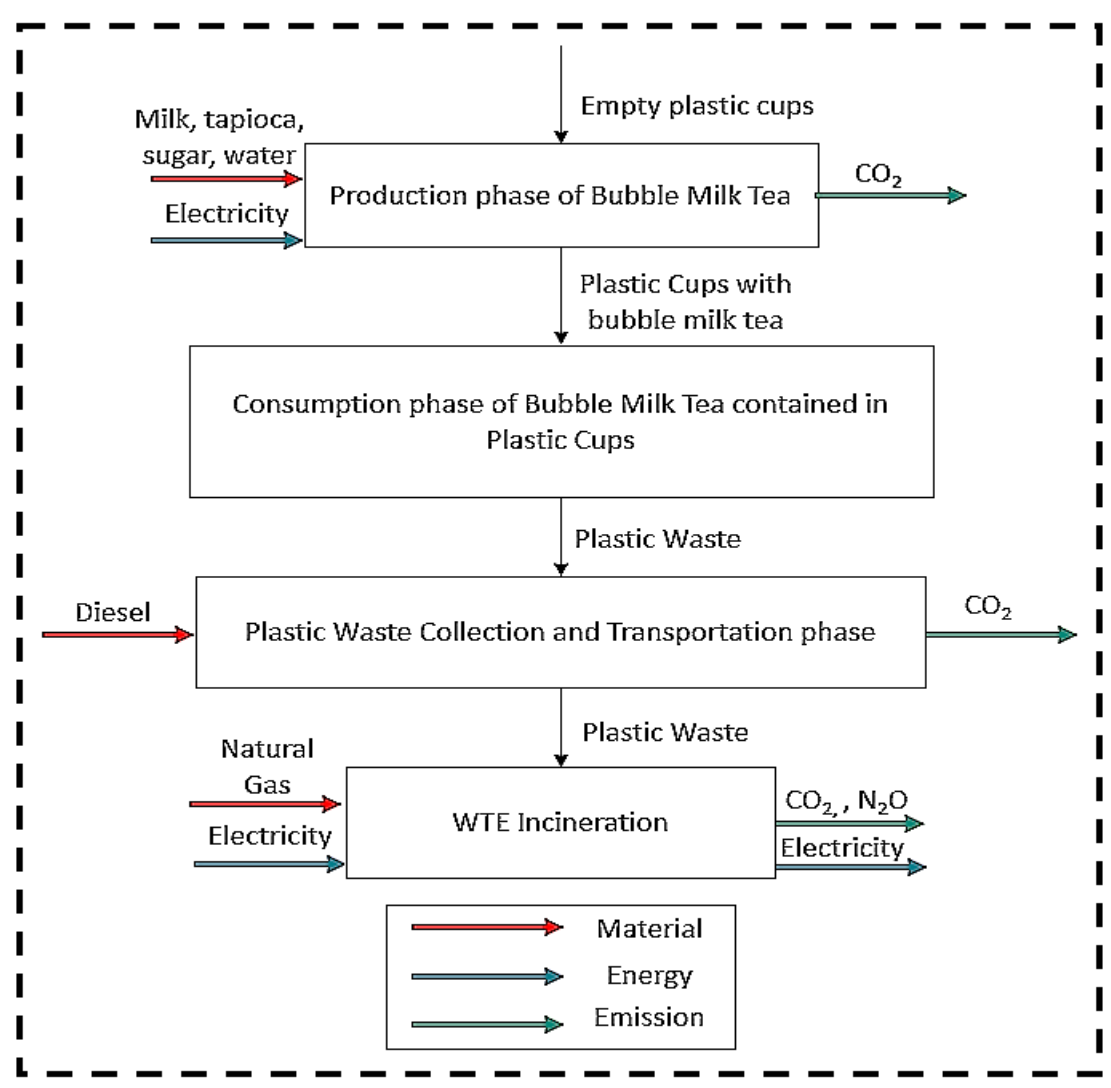

Fig.2 System boundary of plastic waste management for Scenario B 
Assumptions that are made within system boundary of LCA are as following:

1. Only $\mathrm{CO}_{2}, \mathrm{CH}_{4}$ and $\mathrm{N}_{2} \mathrm{O}$ are considered in this study as these gases are the dominant anthropogenic GHG emission by IPCC (Eggleston et al., 2006)

2. Only $\mathrm{CO}_{2}$ is considered for combustion of fossil fuel for transportation and electricity generation as emission factors of $\mathrm{CH}_{4}$ and $\mathrm{N}_{2} \mathrm{O}$ are much smaller than $\mathrm{CO}_{2}$, typically both GHGs contribute to only one percent of overall GHG emission from combustion process (Eggleston et al., 2006)

3. The WTE incinerator besides Jeram Sanitary Landfill is estimated to be ready by year 2023 based but the actual commencement date is unknown (Zainul, 2018).

4. Volume of landfill gas is roughly $50 \% \mathrm{CO}_{2}$ and $50 \% \mathrm{CH}_{4}$ (USEPA, 2020)

5. $\mathrm{CH}_{4}$ is excluded from LCA study as it typically contributes to less than $0.01 \%$ of total GHG emission from incineration (Eggleston et al., 2006)

\section{Life Cycle Inventory}

Life cycle inventory (LCI) is the collection of input and output data related to each phase of plastic waste from bubble tea industry within the system boundary to achieve the goal of LCA study. The main primary data collected in this study are the plastic grade and types of electrical appliances used in the bubble tea shops. The secondary data such as resource and energy inputs as well as emission and energy outputs that are obtained from journal articles and online websites.

\section{Data related to Production of Bubble Milk Tea}

Eq. 1 calculates total electricity consumption of 26 bubble tea shops in Subang Jaya:

$\Phi_{P}=\left(\sum W_{i} \times H R_{\text {Average }} \times N_{\text {Shops }}\right)$

Eq. 2 calculates $\mathrm{CO}_{2}$ emission from the total electricity consumption of these bubble tea shops:

$E_{\mathrm{CO}_{2}, P}=\Phi_{P} \times E F_{\text {mix }}$

Inventory data as equation inputs related to production of bubble milk tea is tabulated in Table 3. 


\begin{tabular}{|c|c|c|c|}
\hline Input Parameters & Unit & Data & Sources \\
\hline \multicolumn{4}{|l|}{ Survey Result } \\
\hline$N_{\text {Shops }}$ & - & 26 & \\
\hline$H R_{\text {Average }}$ & - & 12 & \\
\hline \multicolumn{4}{|c|}{ Energy consumption of electrical appliances } \\
\hline Sealer Machine & & 400.00 & \\
\hline Shaker Machine & & 75.00 & (Mike, 2020) \\
\hline Fructose Dispenser & $\mathrm{W}$ & 300.00 & $\&$ \\
\hline Fridge & & 100.00 & (Draftlogic, 2019) \\
\hline Tube lights (x6) & & $22.00(x 6)$ & \\
\hline \multicolumn{4}{|c|}{ Production emission } \\
\hline $\mathrm{EF}_{\text {mix }}$ & $\mathrm{kg} \mathrm{CO} 2$-eq/kWh & 0.87 & (Fan et al., 2019) \\
\hline
\end{tabular}

\section{Data related to Waste Collection and Transportation}

291 Jeram Sanitary Landfill is responsible for MSW disposal from municipality of Subang Jaya 292 (Yong et al., 2019). Besides this, there is an ongoing project of constructing a WTE incinerator at the Jeram Sanitary Landfill site. Thus, the distance of transportation of 1 tonne of plastic waste for both scenarios are the same. Considering to and fro by the transporter from Subang Jaya to the landfill site as shown in Fig.3, the total two ways distance is $72.40 \mathrm{~km}$ and the diesel consumption is estimated as 10.14 litres for distance of $72.40 \mathrm{~km}$ (Transport, 2020).

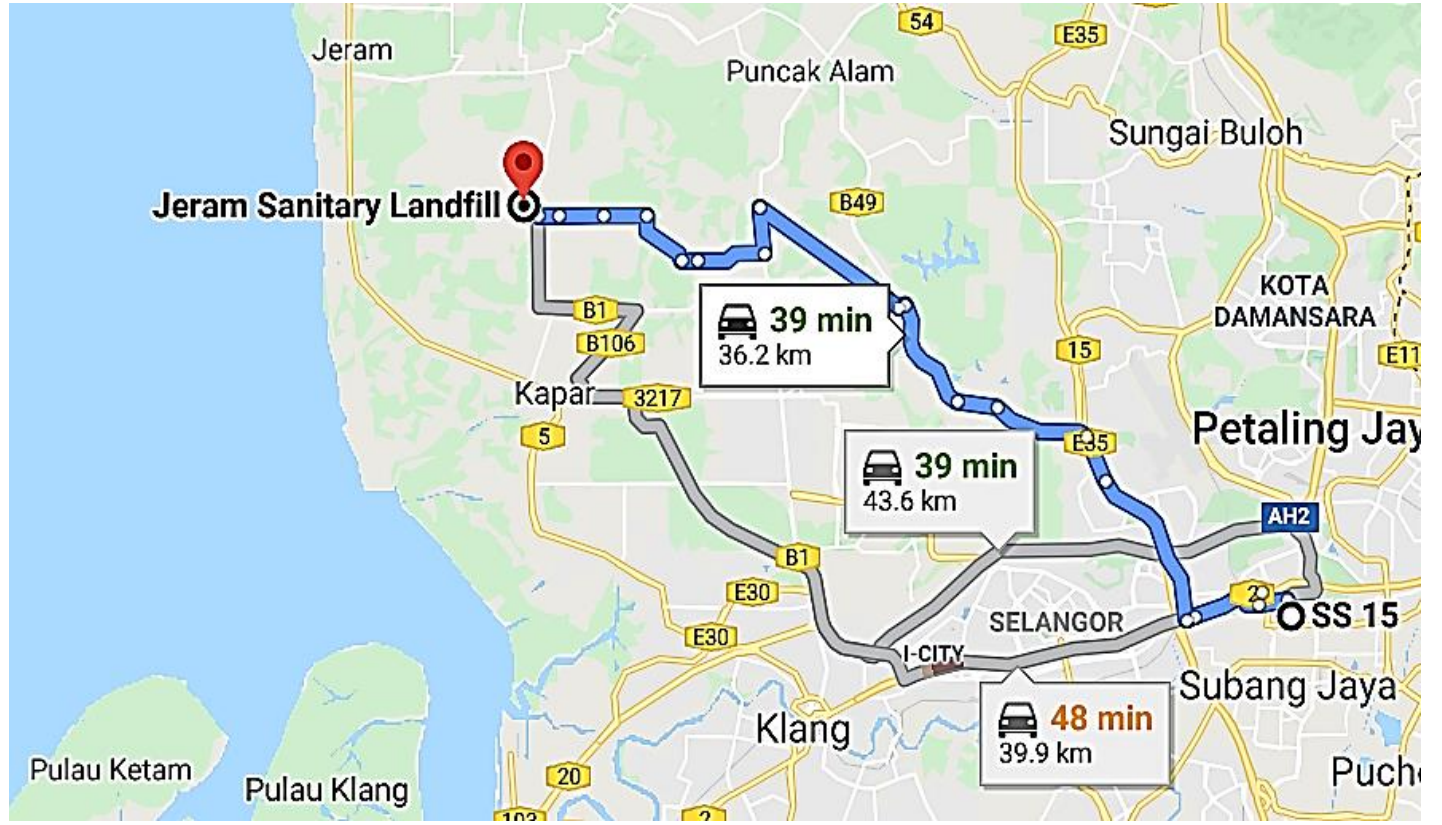

Fig.3 Map showing travel distance from Subang Jaya to Jeram Sanitary Landfill (Maps, 2020) 
300

301

302

303

304

305

306

307

308

309

310

311

312

313

314

315

316

317

318

319

320

321

322

323

Eq. 3 calculates the $\mathrm{CO}_{2}$ emission from road transport (Eggleston et al., 2006).

$E_{\mathrm{CO}_{2}, \mathrm{~T}}=$ Diesel Consumption $\times N C V_{\text {diesel }} \times E F_{\text {diesel }}$

(Eq. 3)

Inventory data as equation inputs related to waste transportation is tabulated in Table 4.

Table 4 Inventory data related to plastic waste transportation

\begin{tabular}{lccc}
\hline Scenario & Unit & Data & Sources \\
\hline Diesel consumption & $\mathrm{kg}$ & 8.62 & (Transport, 2020) \\
$N C V_{\text {diesel }}$ & $\mathrm{MJ} / \mathrm{kg}$ & 43.00 & \\
$\mathrm{EF}_{\text {diesel }}$ & $\mathrm{kg} \mathrm{CO} 2-\mathrm{eq} / \mathrm{TJ}$ & 74100.00 & (Eggleston et al., 2006) \\
\hline
\end{tabular}

\section{Data related to Sanitary Landfill}

Plastic waste in Scenario A is sent to sanitary landfill in Jeram. Emission factor is used to determine the GHG emission from landfill. The emission factor used in this study is an estimated value for a period of 100 years which has taken both $\mathrm{CH}_{4}$ and $\mathrm{CO}_{2}$ into consideration (Eriksson and Finnveden, 2009). Eq. 4 is obtained from the combination of two sources to calculate the $\mathrm{CO}_{2}$ emission from landfill (Eggleston et al., 2006; Fan et al., 2019).

$E_{\mathrm{CO}_{2}, \mathrm{~L}}=\left(\mathrm{PW} \times E F_{\mathrm{CO}_{2}, \mathrm{~L}}\right)+\left(\Phi_{L} \times E F_{\text {mix }}\right)$

Volume of landfill gas emitted, $\boldsymbol{Q}_{\text {landfill }}$ has to be determined in order to determine the volume of $\mathrm{CH}_{4}$ in landfill gas. Eq. 5 is derived using density values of $\mathrm{CH}_{4}$ and $\mathrm{CO}_{2}$ and $E F_{\mathrm{CO}_{2}, L}$.

$E F_{\mathrm{CO}_{2}, \mathrm{~L}} \times \mathrm{PW}=\left(0.5 \times \boldsymbol{Q}_{\text {landfill }} \times \rho_{\mathrm{CO}_{2}} \times 1\right)+\left(0.5 \times \boldsymbol{Q}_{\text {landfill }} \times \rho_{\mathrm{CH}_{4}} \times 28\right)(\mathrm{Eq} .5)$

Eq. 6 calculates the amount of electricity generated from combustion of biogas captured by landfill gas recovery system (LGRS) (Alzate et al., 2019).

Electricity from $\mathrm{CH}_{4}$ combustion $(\mathrm{kWh})=\mathrm{NCV}_{\mathrm{CH}_{4}} \times Q_{\mathrm{CH}_{4}} \times \sigma \times \eta_{L}$

(Eq. 6)

Electricity generation from combustion of $\mathrm{CH}_{4}$ from LGRS of sanitary landfill is considered as renewable and cleaner energy. Thus, we can avoid the combustion of fossil fuels to create the same amount of energy, and the avoided emission from the combustion of fossil fuels is known as GHG saving. Eq. 7 calculates GHG saving in terms of $\mathrm{CO}_{2}$ from electricity generation from LGRS as compared to similar amount of electricity generation from conventional power production in Malaysia (Eggleston et al., 2006; Fan et al., 2019). 
$E_{\mathrm{CO}_{2}, S L}=\left(\right.$ Electricity from $\mathrm{CH}_{4}$ combustion $\left.\times \mathrm{EF}_{\text {mix }}\right)-\left(\right.$ amount of $\mathrm{CH}_{4} \times \mathrm{NCV}_{\mathrm{CH}_{4}} \times$

$\left.325 \mathrm{EF}_{\mathrm{CH}_{4}}\right)$

(Eq. 7)

326 Inventory data as equation inputs related to sanitary landfill is tabulated in Table 5.

Table 5 Inventory data related to sanitary landfill disposal of plastic waste

\begin{tabular}{lccc}
\hline Input Parameters & Unit & Data & Sources \\
\hline Energy and material & & & \\
$\begin{array}{l}\text { Electricity } \\
\text { Landfill emission }\end{array}$ & $\mathrm{kWh}$ & 11.11 & (Eriksson and Finnveden, 2009) \\
$E F_{\mathrm{CO}_{2}, \mathrm{~L}}$ & $\mathrm{~kg} \mathrm{CO}$-eq/t & 271.00 & (Eriksson and Finnveden, 2009) \\
Energy recovery & & & \\
$\sigma$ & - & 0.90 & (Banister and Sullivan, 2011) \\
$\eta_{\mathrm{L}}$ & - & 0.38 & (Eriksson and Finnveden, 2009) \\
Landfill gas property & & & \\
$\rho_{\mathrm{CH}_{4}}$ & $\mathrm{~kg} / \mathrm{m}^{3}$ & 0.66 & (Eggleston et al., 2006) \\
$\rho_{\mathrm{CO}_{2}}$ & $\mathrm{~kg} / \mathrm{m}^{3}$ & 1.98 & \\
$N \mathrm{NV}_{\mathrm{CH}}$ & $\mathrm{kWh} / \mathrm{m}^{3}$ & 9.94 & (Engineeringtoolbox, 2003) \\
$\mathrm{GHG} \mathrm{saving}_{E F_{C H_{4}}}$ & $\mathrm{MJ} / \mathrm{kg}$ & 50.00 & \\
$E F_{m i x}$ & $\mathrm{~kg} \mathrm{CO}$-eq $/ \mathrm{TJ}$ & 54600.00 & (Eggleston et al., 2006) \\
\hline
\end{tabular}

Data related to WTE Incineration

329 Scenario B has the plastic waste been sent to WTE incinerator to reduce the dependence on 330 landfills. Eq.8 is obtained from combination of two sources to calculate $\mathrm{CO}_{2}$ emission from incineration (Eggleston et al., 2006; Fan et al., 2019).

$E_{C O_{2}, I}=\left(\mathrm{PW} \times \mathrm{Dm} \times \mathrm{CF} \times \mathrm{FCF} \times \mathrm{OF} \times \frac{44}{12}\right)+\left(\Phi_{I} \times E F_{\text {mix }}\right)+\left(\right.$ Fuel $\left._{I} \times E F_{\text {gas }}\right)$

333 Eq. 9 calculates $\mathrm{N}_{2} \mathrm{O}$ emission from incineration (Eggleston et al., 2006).

$E_{N_{2} O, I}=\mathrm{PW} \times E F_{N_{2} O, I}$

The energy recovery from incineration in terms of electricity can be calculated using Eq.10 (Alzate et al., 2019). Based on survey result, all 26 bubble tea vendors in Subang Jaya utilise polypropylene (PP) grade 5 plastic as cup material. Hence, net calorific value of plastic in Eq.10 is the net calorific value of PP plastic. 
340 Eq.11 is to calculate GHG saving in terms of $\mathrm{CO}_{2}$-eq from electricity generation from WTE 341 incinerator as compared to similar amount of electricity generated from conventional power 342 production (Fan et al., 2019).

$343 E_{\mathrm{CO}_{2}, \mathrm{SI}}=\left(\right.$ Electricity from Incineration $\left.\times E F_{\text {mix }}\right)$

344 Inventory data as equation inputs related to WTE incineration is tabulated in Table 6.

Table 6 Inventory data related to WTE incineration of plastic waste

\begin{tabular}{|c|c|c|c|}
\hline Input Parameters & Unit & Data & Sources \\
\hline \multicolumn{4}{|c|}{ Energy and material } \\
\hline Electricity $_{I}$ & $\mathrm{kWh}$ & 70 & (Khoo, 2019) \\
\hline Fuel $_{I}$ & MJ & 9.86 & \\
\hline \multicolumn{4}{|c|}{ Incineration emission } \\
\hline$E F_{\text {gas }}$ & $\mathrm{kg} \mathrm{CO}$-eq/TJ & 56100.00 & (Eggleston et al., 2006) \\
\hline$E F_{N_{2} O, I}$ & $\mathrm{~g} \mathrm{~N}_{2} \mathrm{O} / \mathrm{t}$ & 47 & \\
\hline \multicolumn{4}{|l|}{ Plastic property } \\
\hline Dm & - & 0.93 & \\
\hline $\mathrm{CF}$ & - & 0.86 & \\
\hline FCF & - & 0.69 & (Eriksson and Finnveden, 2009) \\
\hline OF & - & 1.00 & \\
\hline \multicolumn{4}{|l|}{ Energy recovery } \\
\hline$N C V_{P P}$ & $\mathrm{kWh} / \mathrm{kg}$ & 11.39 & (Tsiamis and Castaldi, 2016) \\
\hline$\eta_{I}$ & - & 0.30 & (Perrot and Subiantoro, 2018) \\
\hline \multicolumn{4}{|l|}{ GHG saving } \\
\hline$E F_{\operatorname{mix}}$ & $\begin{array}{l}\mathrm{kg} \mathrm{CO}_{2^{-}} \\
\mathrm{eq} / \mathrm{kWh}\end{array}$ & 0.87 & (Fan et al., 2019) \\
\hline
\end{tabular}

Life Cycle Impact Assessment

347 GWP is the only indicator used in this study as the GHGs are the main emission from all phases 348 of LCA. GHGs such as $\mathrm{CH}_{4}$ and $\mathrm{N}_{2} \mathrm{O}$ are converted to $\mathrm{CO}_{2}$-eq by multiplying with their respective GWP as shown in Table 7.

Table 7 Equivalency factor for global warming (Pachauri et al., 2014).

\begin{tabular}{lc}
\hline $\mathrm{GHG}$ & 100 year $\mathrm{GWP}\left(\mathrm{CO}_{2}-\mathrm{eq}\right)$ \\
\hline $\mathrm{CO}_{2}$ & 1 \\
$\mathrm{CH}_{4}$ & 28 \\
$\mathrm{~N}_{2} \mathrm{O}$ & 265 \\
\hline
\end{tabular}




\section{Result and Discussion}

351

352

353

354

355

356

357

358

359

360

361

362

363

364

365

366

367

368

369

370

371

372

373

374

375

376

\section{Scenario A: Baseline Scenario - Sanitary Landfill}

Based on GHG result tabulated in Table 8 and plotted in Fig.4, landfilling has the highest GHG emission as compared to other phases within the system boundary of this LCA study due to potent $\mathrm{CH}_{4}$ emission. Many sanitary landfills in Malaysia have HDPE geomembrane as bottom liners to achieve landfill gas collection efficiency up to $90 \%$ (Banister and Sullivan, 2011). Despite LGRS has a high efficiency to capture $\mathrm{CH}_{4}$ combustion purpose, the uncaptured $\mathrm{CH}_{4}$ is still a main concern as emission of $1 \mathrm{~kg}$ of $\mathrm{CH}_{4}$ is equivalent to emission of $28 \mathrm{~kg} \mathrm{CO}_{2}$ into the environment. The net GWP/GHG emission for sanitary landfill scenario is $566.15 \mathrm{~kg} \mathrm{CO}_{2}$ eq per tonne of plastic waste after taking into consideration the GHG saving of $15.32 \mathrm{~kg} \mathrm{CO}_{2}$ eq achieved from the electricity generation from combustion of captured $\mathrm{CH}_{4}$.

New study has found out that $\mathrm{CH}_{4}$ emission from plastic waste has continued at night once the plastic waste is exposed to ambient solar radiation and the exposed aged plastic will release more $\mathrm{CH}_{4}$ at night (Malekmian, 2018). $\mathrm{CH}_{4}$ emission from this new study is neither accounted in the journal articles, LCA software nor accounted by the equations listed by IPCC, therefore the actual GHG emission from landfilling is expected to be higher than the predicted value of $280.67 \mathrm{~kg} \mathrm{CO}$-eq. Electricity consumption from production of bubble milk tea is ranked second in terms of GHG emission which has contributed to $273.34 \mathrm{~kg} \mathrm{CO}_{2}$-eq followed by small amount of GHGs released from mobile combustion of diesel for transportation and stationary combustion of $\mathrm{CH}_{4}$ for electrcity generation. These four activities have combined to give the gross GWP/GHG emission of $581.47 \mathrm{~kg} \mathrm{CO}_{2}$-eq.

Up to date, only $6 \%$ of the landfills in Malaysia are sanitary and as a result, landfilling is still the primary $\mathrm{CH}_{4}$ emission source in Malaysia. Therefore, the first step for local authorities to implement sustainable plastic waste management plan is to phase out non-sanitary landfills or upgrade these landfills into sanitary ones. With LGRS featured into these upgraded landfills, GHG emission is reduced by $15.32 \mathrm{~kg} \mathrm{CO}_{2}$-eq for every tonne of plastic waste that is diposed into landfill. 

(Scenario A)

\begin{tabular}{|c|c|c|}
\hline LCA phases & Unit & Values \\
\hline \multicolumn{3}{|l|}{ A) Production of bubble milk tea } \\
\hline $\begin{array}{l}\text { Electricity consumption for daily operation of } \\
\text { bubble tea shops in Subang Jaya }\end{array}$ & $\mathrm{kWh}$ & 314.18 \\
\hline Total GHG for production of bubble milk tea & kg CO $2-e q$ & 273.34 \\
\hline \multicolumn{3}{|l|}{ B) Transportation } \\
\hline $\begin{array}{l}\text { Diesel consumption for transportation of plastic } \\
\text { waste from Bubble Tea Street in Subang Jaya to } \\
\text { Jeram Sanitary Landfill for two way distance of } 72.4 \\
\mathrm{~km}\end{array}$ & $\mathrm{~L}$ & 10.14 \\
\hline Total GHG for transportation & kg CO $2-e q$ & 27.46 \\
\hline \multicolumn{3}{|l|}{ C) Landfilling } \\
\hline Electricity consumption for compacting the waste & $\mathrm{kWh}$ & 11.11 \\
\hline $\mathrm{CO}_{2}$ emission from electricity consumption & $\mathrm{kg} \mathrm{CO}_{2}$-eq & 9.67 \\
\hline $\mathrm{CO}_{2}$ emission from landfill & $\mathrm{kg} \mathrm{CO}_{2}-\mathrm{eq}$ & 26.23 \\
\hline $\mathrm{CH}_{4}$ emission (Convert to GWP unit) & $\mathrm{kg} \mathrm{CO}_{2}-\mathrm{eq}$ & 244.77 \\
\hline Total GHG for landfilling & kg CO 2 -eq & 280.67 \\
\hline Gross GHG emission & kg CO $2-e q$ & 581.47 \\
\hline \multicolumn{3}{|l|}{ D) Electricity generation } \\
\hline Electrcity generated & $\mathrm{kWh}$ & 45.03 \\
\hline $\mathrm{CO}_{2}$ emission from $\mathrm{CH}_{4}$ combustion & $\mathrm{kg} \mathrm{CO}_{2}$-eq & 23.86 \\
\hline $\mathrm{CO}_{2}$ emission based on electricity generation mix & $\mathrm{kg} \mathrm{CO}_{2}-\mathrm{eq}$ & -39.18 \\
\hline Total GHG saving & kg CO $2-e q$ & -15.32 \\
\hline Net GHG emission $(A+B+C+D)$ & $\mathrm{kg} \mathrm{CO}_{2}$-eq & 566.15 \\
\hline
\end{tabular}

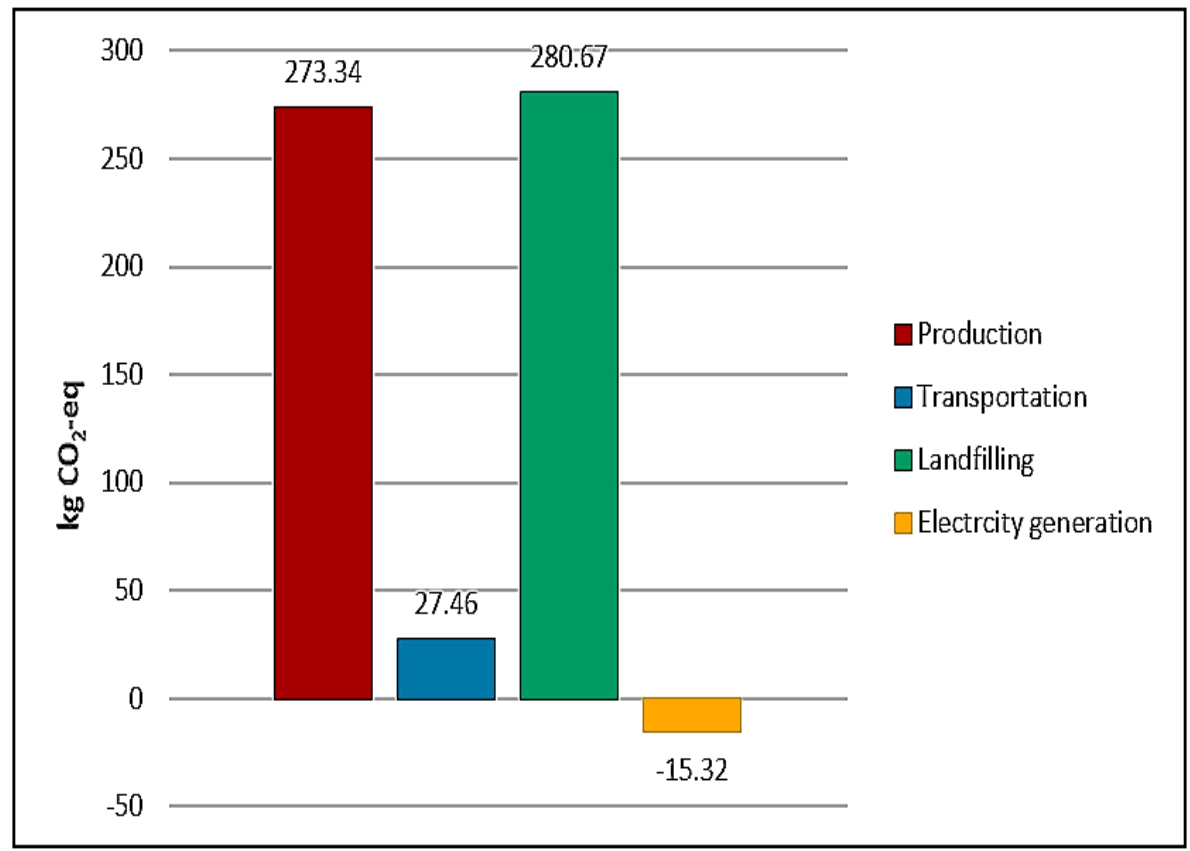

Fig.4 GHG emission of the activities involved in sanitary landfill disposal of 1 tonne of 


\section{Scenario B: WTE incineration}

383 Based on Table 9 and Fig.5, the GHG emission from production of bubble milk tea, 384 transportation and incineration of plastic waste have combined to generate a gross GWP of $3852398.99 \mathrm{~kg} \mathrm{CO}$-eq. The GHG emission from production phase of bubble milk tea and 386 transportation phase of plastic waste in Scenario B is similar to the values obtained from 387 Scenario A as expected as the input data for LCA study of these two phases are similar for both 388 scenarios.

389

390

391

392

393

394

395

396

397

398

399

400

401

402

403

404

405

Incineration process has the highest GHG emission as compared to other phases and the emission is greater than the main GHG contributor in Scenario A - landfilling by $1817.52 \mathrm{~kg}$ $\mathrm{CO}_{2}$-eq. The high GHG emisison is due to higher net calorific value of the plastic. The PP plastic has a net calorific value of $41 \mathrm{MJ} / \mathrm{kg}$ which is about four times greater than the average calorific value of MSW in Malaysia of $10.88 \mathrm{MJ} / \mathrm{kg}$ (Tsiamis and Castaldi, 2016; Yong et al., 2019). The higher the calorific value of waste, the greater amount of heat energy can be extracted from the waste and this leads to higher GHG emission. However, the actual GHG emission from incineration is much lower as the equations provided by IPCC guidelines did not take in acocunt of reduction in carbon emission by advanced air pollution control system such as scrubber and activated carbon filter that are featured in the modern WTE incinerators. Nevertheless, the net GWP of WTE incineration is $-573.80 \mathrm{~kg} \mathrm{CO}_{2}$-eq and the huge reduction in GWP is contributed by huge GHG saving achieved from electricity generation by the WTE incinerator which is much cleaner than conventional power production practice of Malaysia. Astonishing amount of 3.42 MWh of electricity is generated due to high net calorific value of plastic waste and this has led to a GHG saving of $2972.79 \mathrm{~kg} \mathrm{CO}_{2}$-eq. Higher amount of electricity can be generated and greater GHG saving can be obtained if the electrical conversion efficiency of WTE incinerator is higher than $30 \%$. 
Table 9 Net GHG emission of WTE incineration of 1 tonne of plastic waste for Scenario B

\begin{tabular}{|c|c|c|}
\hline LCA phases & Unit & Values \\
\hline \multicolumn{3}{|l|}{ A) Production of bubble milk tea } \\
\hline $\begin{array}{l}\text { Electricity consumption for daily operation of bubble tea shops } \\
\text { in Subang Jaya }\end{array}$ & $\mathrm{kWh}$ & 314.18 \\
\hline Total GHG for production of bubble milk tea & kg CO 2 -eq & 273.34 \\
\hline \multicolumn{3}{|l|}{ B) Transportation } \\
\hline $\begin{array}{l}\text { Diesel consumption for transportation of plastic waste from } \\
\text { Bubble Tea Street in Subang Jaya to Jeram Sanitary Landfill for } \\
\text { two way distance of } 66.4 \mathrm{~km}\end{array}$ & $\mathrm{~L}$ & 10.14 \\
\hline Total GHG for transportation & $\mathrm{kg} \mathrm{CO}_{2}$-eq & 27.46 \\
\hline \multicolumn{3}{|l|}{ C) Incineration } \\
\hline Natural gas consumption as auxiliary fuel for process startup & MJ & 9.86 \\
\hline $\mathrm{CO}_{2}$ emission from fuel consumption & $\mathrm{kg} \mathrm{CO}$-eq & 0.55 \\
\hline Electricity consumption for process startup & $\mathrm{kWh}$ & 70 \\
\hline $\mathrm{CO}_{2}$ emission from electricity consumption & $\mathrm{kg} \mathrm{CO}$-eq & 60.90 \\
\hline $\mathrm{CO}_{2}$ emission from incineration & $\mathrm{kg} \mathrm{CO}_{2}$-eq & 2023.49 \\
\hline $\mathrm{N}_{2} \mathrm{O}$ emission (Convert to GWP unit) & $\mathrm{kg} \mathrm{CO}$-eq & 13.25 \\
\hline Total GHG for incineration & $\mathrm{kg} \mathrm{CO}_{2}$-eq & 2098.19 \\
\hline Gross GHG emission & $\mathrm{kg} \mathrm{CO}$-eq & 2398.99 \\
\hline \multicolumn{3}{|l|}{ D) Electricity generation } \\
\hline Electrcity generated & $\mathrm{kWh}$ & 3417.00 \\
\hline $\mathrm{CO}_{2}$ emission based on electricity generation mix & $\mathrm{kg} \mathrm{CO}_{2}$-eq & -2972.79 \\
\hline Total GHG saving & kg CO 2 -eq & -2972.79 \\
\hline Net GHG emission $(A+B+C+D)$ & kg CO 2 -eq & -573.80 \\
\hline
\end{tabular}

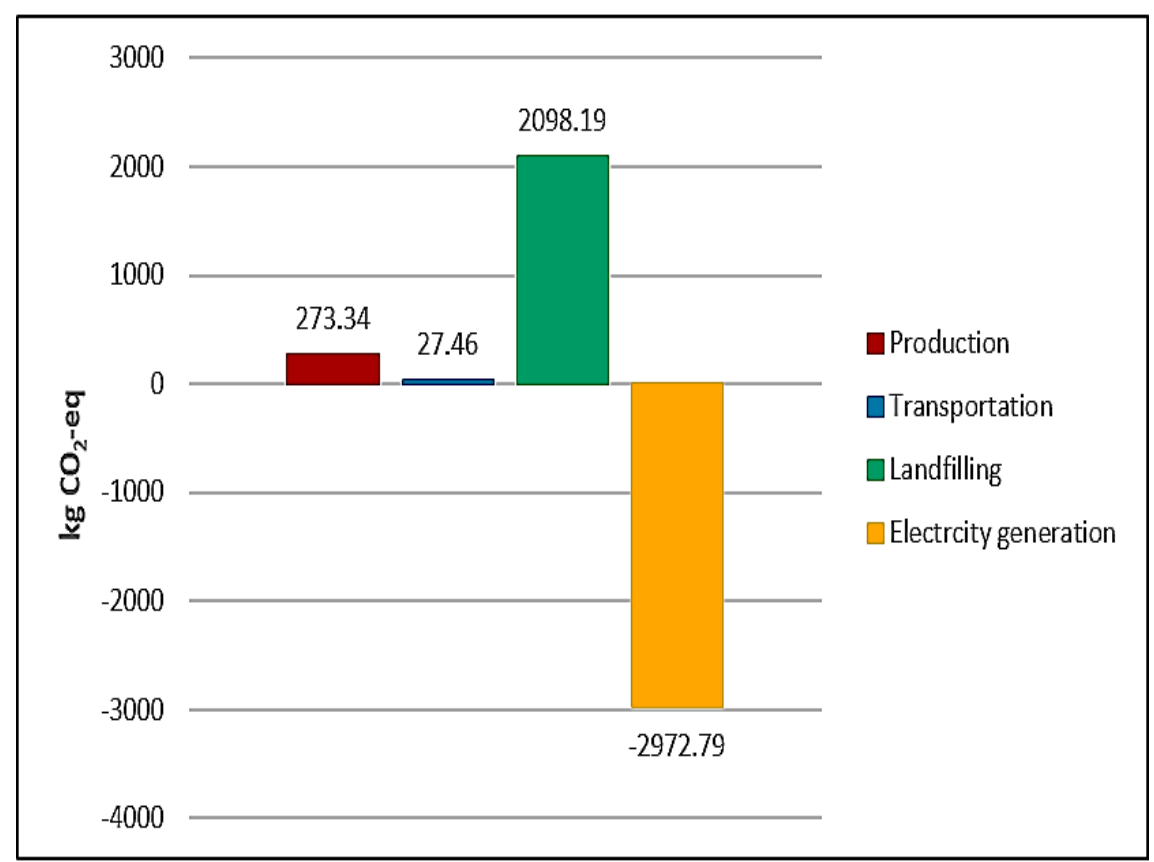

Fig.5 GHG emission of the activities involved in WTE incineration of 
412 Based on net GHG emission/GWP for two plastic waste management scenarios as shown in 413 Fig.6, the overall comparison of both scenarios indicates that Scenario B (WTE incineration) 414 is the better option in terms of environmental sustainability where it has a negative net GWP 415 and it is able to achieve GHG reduction of $1139.95 \mathrm{~kg} \mathrm{CO}_{2}$-eq/t of plastic waste being sent to 416 WTE incineration instead of the baseline scenario (sanitary landfill). Besides this, WTE 417 incineration is able to generate 3.42 MWh of electrcity per tonne of plastic waste as compared 418 to sanitray landfill where only $45.03 \mathrm{kWh}$ of electricty is generated for every tonne of plastic 419 waste. Moreover, plastic waste disposal phase is the primary hotspot for GWP in both scenarios 420 as waste management technologies and electricity generation are both under plastic waste 421 disposal phase which have significant impacts on net GHG emission.

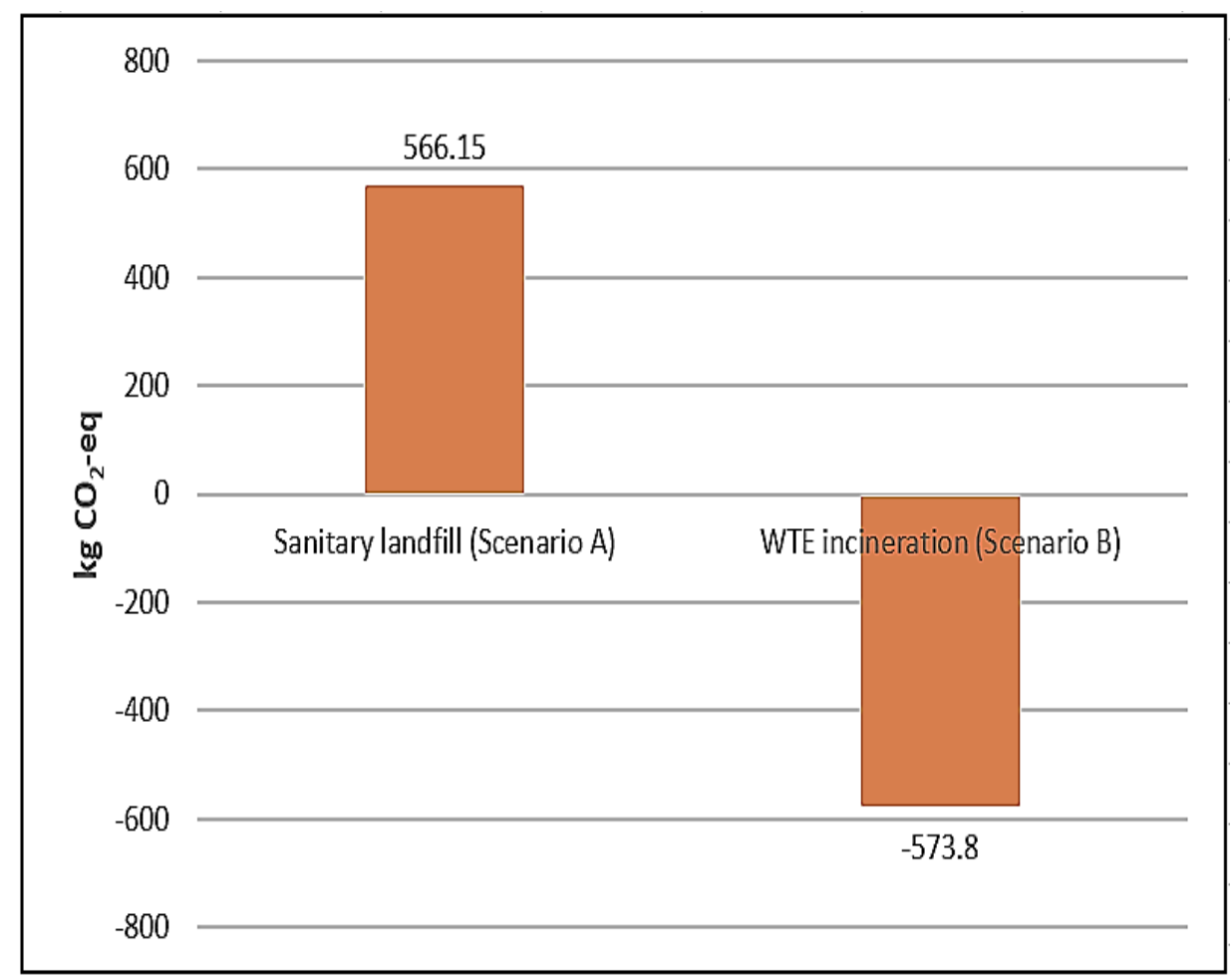

424 It is better to keep $\mathrm{GHG}$ emission of $\mathrm{N}_{2} \mathrm{O}$ and $\mathrm{CH}_{4}$ as low as possible because these gases have higher GWP. $\mathrm{CH}_{4}$ is the main GHG from landfilling whereas $\mathrm{N}_{2} \mathrm{O}$ is the main GHG from incineration. Although the GWP of $\mathrm{N}_{2} \mathrm{O}$ is 9.46 times greater than $\mathrm{CH}_{4}$, mass fraction of $\mathrm{N}_{2} \mathrm{O}$ only accounts for $0.78 \%$ of the hot flue gas exiting the WTE incinerator as opposed to sanitary landfill where $\mathrm{CH}_{4}$ accounts for $25 \%$ of total mass fraction of landfill gas. When comparing both GHG emission per tonne of plastic waste in terms of $\mathrm{kg} \mathrm{CO}_{2}$-eq, $\mathrm{CH}_{4}$ emission from sanitary landfill and $\mathrm{N}_{2} \mathrm{O}$ emission from WTE incinerator are $244.77 \mathrm{~kg} \mathrm{CO}_{2}$-eq and $13.25 \mathrm{~kg}$ 
$\mathrm{CO}_{2}$-eq respectively. As a result, WTE incineration is more environmental friendly choice if the study is to focus on reduction of GWP attributed by these two potent GHGs.

433

434

435

436

437

438

439

440

441

442

In the incineration process, combustion of plastic waste under high temperature generates huge amount of $\mathrm{CO}_{2}$ which contributes significantly to global warming and rapid climate change. However, the high GWP is compensated by GHG saving via electricity generation from incineration where the emission is lower than conventional power production. While the electrcity conversion effeciency of both sanitary landfill and WTE incinerator are within the range of 30 to $40 \%$, the energy recovery from incineration is much greater than landfill due to higher electrcity generation. The recovery difference is mainly due to the amount of fuels being combusted in both energy recovery systems. Energy recovery of WTE incinerator is greater as compared to sanitary landfill as the entire 1 tonne of plastic waste is consumed and converted to heat energy, unlike LGRS of sanitary landfill where only the $\mathrm{CH}_{4}$ composition of captured landfill gas $(8.74 \mathrm{~kg})$ produced from landfill disposal of 1 tonne of plastic waste is consumed and converted to heat energy with remaning $\mathrm{CO}_{2}$ and uncaptured $\mathrm{CH}_{4}$ are released to the environment. Moroever, characteristic of $\mathrm{CH}_{4}$ is almost similar to natural gas in which there is only slight GHG saving when comparing emission from electrcity generated from combustion of $\mathrm{CH}_{4}$ with conventional power production of Malaysia.

Based on the LCA result on GHG emission, WTE incineration can be an effective alternative to improve plastic waste management as it can divert more plastic waste from the sanitary landfill and offer GHG saving through electricity generation from plastic waste. Tsiamis and Castaldi (2016) mentioned that the average net calorific value of all 7 grades of petroleumbased plastic is $35.7 \mathrm{MJ} / \mathrm{kg}$ or $9.92 \mathrm{kWh} / \mathrm{kg}$ and $\mathrm{GHG}$ saving of $2589.12 \mathrm{~kg} \mathrm{CO}$-eq can be achieved with the net GWP is remained as a negative figure with the amount of $-190.13 \mathrm{~kg}$ $\mathrm{CO}_{2}$-eq if average net calorific value of all plastic grades is used for environmental impact assessment of Scenario B instead of using net calorific value of PP plastic alone.

In conclusion, WTE incineration treatment is proven as a carbon negative technology and can be used as the basis of environmental sustainability framework development for plastic waste management that is previously developed based on sanitary landfill to tackle single-use plastic waste from Bubble Tea Streets of Subang Jaya in order to create a cleaner environment and to prevent the increase in global temperature caused by single-use plastics. 
Environmental Sustainability Framework for Plastic Waste Management in Bubble Tea Streets of Subang Jaya, Malaysia

463 Growth of food and beverage industries such as bubble tea industry accelerates the generation 464 of single-use plastic waste. These low quality petroleum based plastics take longer time to degrade as compared to other types of solid waste and thus, taking up more spaces in landfills in the long run. As a result, government is seeking for alternative WTE incineration to replace landfills for plastic waste disposal but the environmental performance of this alternative is still unknown. However, it was proven from LCA study that a negative net GWP of $-573.80 \mathrm{~kg}$ $\mathrm{CO}_{2}$-eq is achieved for every tonne of plastic waste being sent to WTE incinerator, a further confirmation that WTE incineration is more environmnetal friendly than sanitary landfill.

Materialise a plastic waste management framework in a sustainable way is a challenging and difficult task which cannot simply be done by government alone. Besides reducing global warming impact and the dependence on landfill with implementation of WTE incineration, the responsibility to ensure a successful and effective development plastic waste management framework is shared among the government, bubble tea vendors, waste contractors and consumers. This framework assumes bubble tea business is carried out in normal course of business without being affected by coronavirus pandemic.

Government plays an important role in ensuring continuity of a proposed environmental sustainable plastic waste management framework. Besides enforcing stringent regulations on plastic littering, collection and sorting of plastic waste by vendors as well as controlling air emission from incinerators, government can allocate more plastic waste bins around Bubble Tea Streets to provide convenience to customers for disposing the plastic cups after consumption of bubble milk tea. Besides, the government can also encourage these bubble tea vendors to seek alternatives to phase out single-use plastic cups. Alternatively, government can enforce a total ban on single-use plastics which is proven to be very effective to indirectly forcing the vendors to utilise environmental friendlier cup material as soon as possible (Ali et al., 2021). Next, government can appoint reputable sanitation company to collect waste from collection bins to ensure Subang Jaya is always free of plastic waste before transporting it to the waste management company. 
490 Establishing a WTE incinerator requires high capital cost and government can provide assistance in capital in the form of waste management subsidy or grant. The government can then enter into a contract agreement with waste management company, which is the owner of WTE incinerator in this case, to agree on duration of its operation and ensure standard fees are charged for waste disposal. Municipal plastic waste is considered as renewable biomass source and the government pays money directly to the waste management company in exchange for electricity that is being sold to Tenaga National Berhad (TNB) in accordance to the Feed-In Tariff (FIT) rates provided by Sustainable Energy Development Authority (SEDA) Malaysia (SEDA, 2020). Part of these renewable energy can be supplied to the bubble tea vendors in Subang Jaya to run their daily business activities which require an average of $314.18 \mathrm{kWh}$ of electricty. Thus, a conclusion can be made in which more electricity can be generated and greater GHG saving can be achieved if more single-use plastic waste are being incinerated instead of landfilling.

According to waste management hierarchy, reduce and reuse are better waste management options as compared to waste treatment and disposal. Therefore, plastic waste should be reduced instead of sending the waste to incinerator for electrcity generation without taking any initiative to reduce the GHG emission from incineration. Bubble tea vendors can do their parts in reducing plastic waste and to spread plastic pollution awareness among the public by utilising paper or biodegradable plastic cups to phase out single-use plastics. Moreover, bubble tea vendors can encourage customers to bring their own tumblers by giving them incentives such as discount or drink rewards thus cutting down plastic waste pollution. Furthermore, bubble tea shops can also introduce resuable tumblers.

The role of waste management company is to keep the discharged $\mathrm{CO}_{2}$ as low as possible in order to comply with the stringent regulation set by the Department of Environment (DOE). With the financial support from government, further upgrades can be done on the existing advanced air pollution control system which are featured in the WTE incinerator to further reduce the GHG emission coming out from the chimney.

The proposed environmental sustainability framework for plastic waste management in Subang Jaya can be further visualised in Fig.7. The framework highlights on the role of each party to manage and reduce the GHG emission associated with plastic waste. The framework also suggest alternative ways to reduce the use of plastics. 


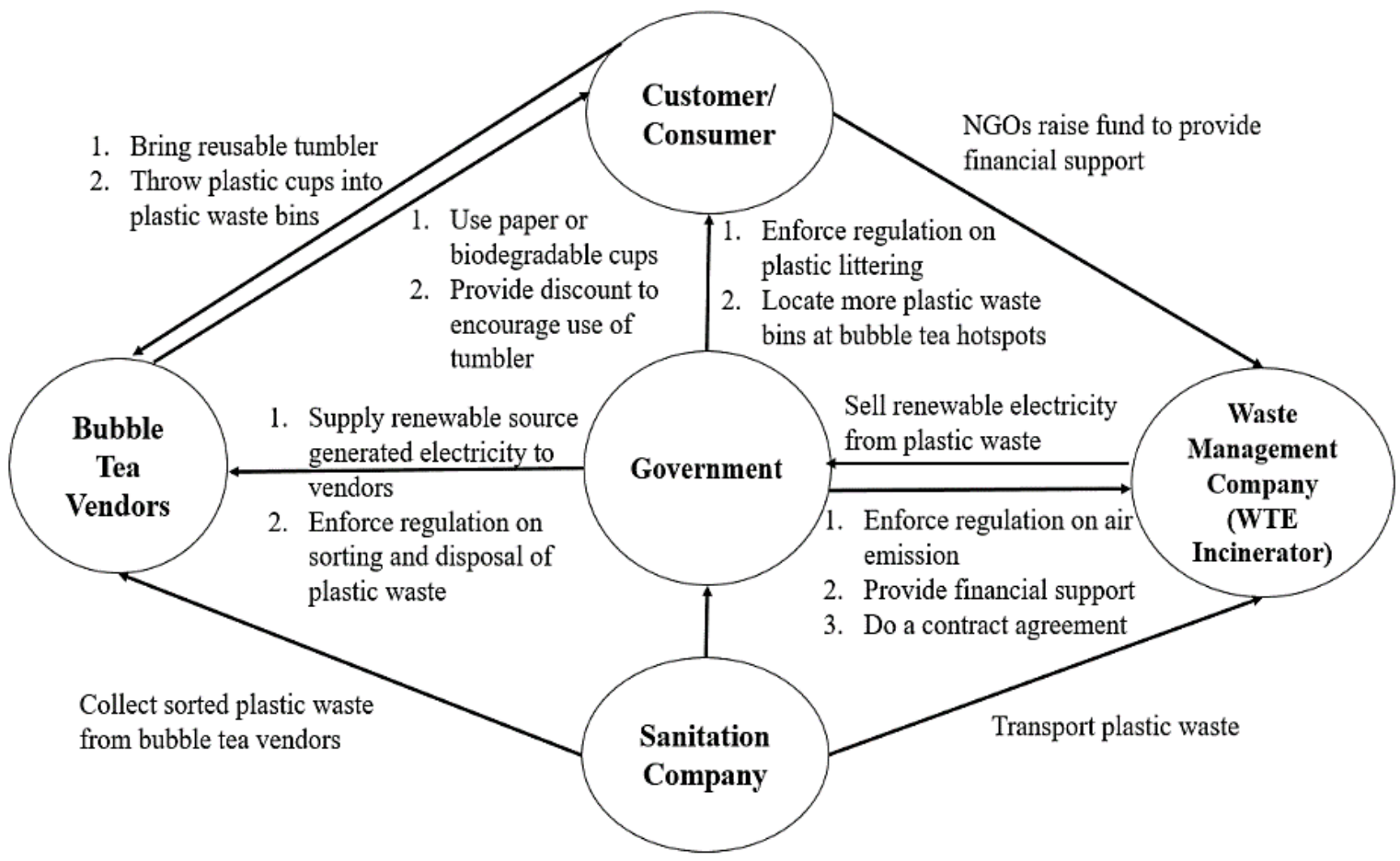

Fig.7 Proposed environmental sustainability framework for plastic waste management in

Bubble Tea Streets of Subang Jaya

\section{Conclusion}

527 Based on the study, WTE incineration is proven to be more environmental friendly as compared 528 to sanitary landfill. The GHG emission in terms of $\mathrm{CO}_{2}$-eq of sanitary landfill and WTE incineration are $566.15 \mathrm{~kg} \mathrm{CO}_{2}$-eq and $-573.80 \mathrm{~kg} \mathrm{CO}_{2}$-eq respectively. The main contributor that leads to a negative net GHG emission in overall environmental performance of WTE incineration is the huge GHG saving achieved from the renewable electrical energy generated from incineration. This is because Malaysia is highly depending on fossil fuels for electricity generation and the GHG emission to create useful energy from conventional power production is much greater as compared to WTE incineration. Hence, the power production practice of Malaysia has a significant impact on net GHG emission of WTE incineration. The environmental feasibility of implementing WTE technology might be altered in the future if the renewable energy sources have higher share in power production practice. The result suggests that GHG saving could be further increased if energy conversion efficiency of WTE incineration can be increased to be more than $30 \%$ for greater electricity generation or further improve the technology of advanced air pollution control system to further reduce the GHG emission into the environment. 
542 The proposed environmental sustainability framework for plastic waste management aims to 543 showcase a general idea for the government to deal with increasing solid waste issue, especially 544 on plastic waste caused by heavy usage of single-use plastics from the bubble tea industry. If 545 this framework was deemed to be successful upon its implementation, it can be considered by 546 government to implement on other plastic waste generation hotspots other than bubble tea 547 industry or as a reference to enable policy makers to have a clearer idea on implementing a 548 better and more sustainable Twelfth Malaysia 2021 - 2025 solid waste management plan.

549 The result of LCA can be improved by obtaining the latest data regarding waste sector of 550 Malaysia from relevant authorities in order to reduce the number of assumptions made. 551 Moreover, LCA software can be used for analysis for more detailed calculations to verify the 552 results obtained from this study. Although GWP is the main environmental impact indicator 553 when dealing with plastic waste, other minor environmental impact indicators should be taken 554 into consideration to assess the overall environmental performance of existing sanitary landfill 555 and alternative WTE incinerator. Furthermore, a more comprehensive study such as economic 556 and social aspects of WTE incineration and sanitary landfill should be taken into consideration 557 to help policy makers to implement better plastic waste management plan that benefits all 558 parties that are dealing with plastic waste issue.

\section{Declaration}

560 Ethics Approval \& Consent to Participate

561 Not applicable.

562 Consent for Publication

563 Not applicable.

\section{Availability of Data \& Materials}

565 The dataset used and/or analysed during the current study are available from the author on 566 reasonable request.

\section{Competing Interests}

568 The authors declare that they have no competing interests. 
No fund/grant is received for the current study.

571

572

\section{Authors' Contributions}

The first author (CJ) conducted the study and wrote the manuscript. The second author (LC) edited the manuscript. The corresponding author (JT) checked and proofread the manuscript.

\section{References}

Abdullah, W. S. W., Osman, M., Ab Kadir, M. Z. A. \& Verayiah, R. 2019. The potential and status of renewable energy development in Malaysia. Energies, 12, 2437.

Ali, S., Ahmed, W., Solangi, Y. A., Zarei, N. \& Chaudhry, I. S. 2021. Strategic analysis of single-use plastic ban policy for environmental sustainability: the case of Pakistan. Clean Technologies and Environmental Policy.

Alias, F. S., Abd Manaf, L., Ariffin, M. \& Abdullah, S. H. 2018. Solid waste minimization in Malaysia. Pertanika Journal of Scholarly Research Reviews, 4.

Alzate, S., Restrepo-Cuestas, B. \& Jaramillo-Duque, Á. 2019. Municipal solid waste as a source of electric power generation in Colombia: A techno-economic evaluation under different scenarios. Resources, 8, 51.

Arvanitoyannis, I. S. 2008. ISO 14040: life cycle assessment (LCA)-principles and guidelines.

Aziz, A. 2020. Another due date for country's 1st WTE plant. The Malaysian Reserve, 23 September 2020.

Banister, A. V. K. \& Sullivan, P. S. 2011. LFG collection efficiency: debunking the rhetoric. MSW Managemnet.

Draftlogic. 2019. List of the Power Consumption of Typical Household Appliances [Online]. Draft Logic. Available: https://www.daftlogic.com/information-appliance-powerconsumption.htm [Accessed 10 May 2020].

Eggleston, S., Buendia, L., Miwa, K., Ngara, T. \& Tanabe, K. 2006. 2006 IPCC guidelines for national greenhouse gas inventories, Institute for Global Environmental Strategies Hayama, Japan.

Engineeringtoolbox. 2003. Fuels - Higher and Lower Calorific Values [Online]. Available: https://www.engineeringtoolbox.com/fuels-higher-calorific-values-d 169.html [Accessed 12 May 2020]. 
Eriksson, O. \& Finnveden, G. 2009. Plastic waste as a fuel-CO 2-neutral or not? Energy \&

Environmental Science, 2, 907-914.

Fan, Y. V., Klemeš, J. J., Lee, C. T. \& Perry, S. 2019. GHG emissions of incineration and anaerobic digestion: Electricity mix. Chemical Engineering Transactions, 72, 145-150.

Geyer, R., Jambeck, J. R. \& Law, K. L. 2017. Production, use, and fate of all plastics ever made. Science advances, 3, e1700782.

Google Maps. 2020. Travel distance from SS15, Subang Jaya to Jeram Sanitary Landfill.

Kaza, S., Yao, L., Bhada-Tata, P. \& Van Woerden, F. 2018. What a waste 2.0: a global snapshot of solid waste management to 2050, The World Bank.

Khoo, H. H. 2019. LCA of plastic waste recovery into recycled materials, energy and fuels in Singapore. Resources, Conservation and Recycling, 145, 67-77.

KPKT. 2015. Solid Waste Management Lab 2015: Final Lab Report. Ministry of Housing and Local Government. Putrajaya, Malaysia.

Lew, R. 2020. Moving Grate Incineration: Preferred WTE Technology [Online]. Bioenergy Consult. Available: https://www.bioenergyconsult.com/moving-grate-incineration/ [Accessed 22 April 2020].

Malekmian, S. 2018. Plastic waste emits greenhouse gases when exposed to sunlight. Green News, 13 August 2018.

Mike, R. 2020. Bubble Tea Store Design Layout [Online]. Bubble Teaology. Available: https://www.bubbleteaology.com/bubble-tea-store-design-layout/ [Accessed 10 May 2020].

Pachauri, R. K., Allen, M. R., Barros, V. R., Broome, J., Cramer, W., Christ, R., Church, J. A., Clarke, L., Dahe, Q. \& Dasgupta, P. 2014. Climate change 2014: synthesis report. Contribution of Working Groups I, II and III to the fifth assessment report of the Intergovernmental Panel on Climate Change, Ipcc.

Perrot, J.-F. \& Subiantoro, A. 2018. Municipal waste management strategy review and wasteto-energy potentials in New Zealand. Sustainability, 10, 3114.

Ritchie, H. \& Roser, M. 2017. $\mathrm{CO}_{2}$ and Greenhouse Gas Emissions. Our world in data.

Ritchie, H. \& Roser, M. 2018. Plastic pollution. Our World in Data.

SEDA. 2020. Feed-In Tariff (FIT) [Online]. Available: http://www.seda.gov.my/reportal/fit/ [Accessed 27 May 2020].

Tan, J, Tan, R. R., Aviso, K. B., Promentilla, M. A. B., Nik Sulaiman, N. M. (2017), Study of microalgae cultivation systems based on integrated analytic hierarchy process-life cycle optimization. Clean Technologies and Environment Policy, 19(8), 2075-2088. 
Tan, M. Z. 2019. Malaysia has 74 bubble tea brands, can you tell them all apart? Malay Mail, 24 July 2019.

Transport. 2020. China: Heavy-duty: Fuel Consumption [Online]. Transport Policy.

Available: https://www.transportpolicy.net/standard/china-heavy-duty-fuel-consumption/ [Accessed 11 May 2020].

Tsiamis, D. A. \& Castaldi, M. J. 2016. Determining accurate heating values of non-recycled plastics (NRP). Earth Engineering Center City, University of New York, New York.

USEPA. 2016. Air Emissions from MSW Combustion Facilities [Online]. United States Environmental Protection Agency. Available:

https://archive.epa.gov/epawaste/nonhaz/municipal/web/html/airem.html [Accessed 5 April 2020].

USEPA. 2020. Basic Information about Landfill Gas [Online]. United States Environmental Protection Agency. Available: https://www.epa.gov/lmop/basic-information-about-landfillgas [Accessed 17 April 2020].

Van Caneghem, J., Van Acker, K., De Greef, J., Wauters, G. \& Vandecasteele, C. 2019. Waste-to-energy is compatible and complementary with recycling in the circular economy. Clean Technologies and Environmental Policy, 21, 925-939.

Wang, W., Themelis, N. J., Sun, K., Bourtsalas, A. C., Huang, Q., Zhang, Y. \& Wu, Z. 2019. Current influence of China's ban on plastic waste imports. Waste Disposal \& Sustainable Energy, 1, 67-78.

Yong, Z. J., Bashir, M. J., Ng, C. A., Sethupathi, S., Lim, J. W. \& Show, P. L. 2019. Sustainable Waste-to-Energy Development in Malaysia: Appraisal of Environmental, Financial, and Public Issues Related with Energy Recovery from Municipal Solid Waste. Processes, 7, 676.

Zainul, E. 2018. Worldwide Holdings to spend RM1b to develop waste-to-energy system in Selangor. The Edge Markets, 10 December 2018. 
Figures

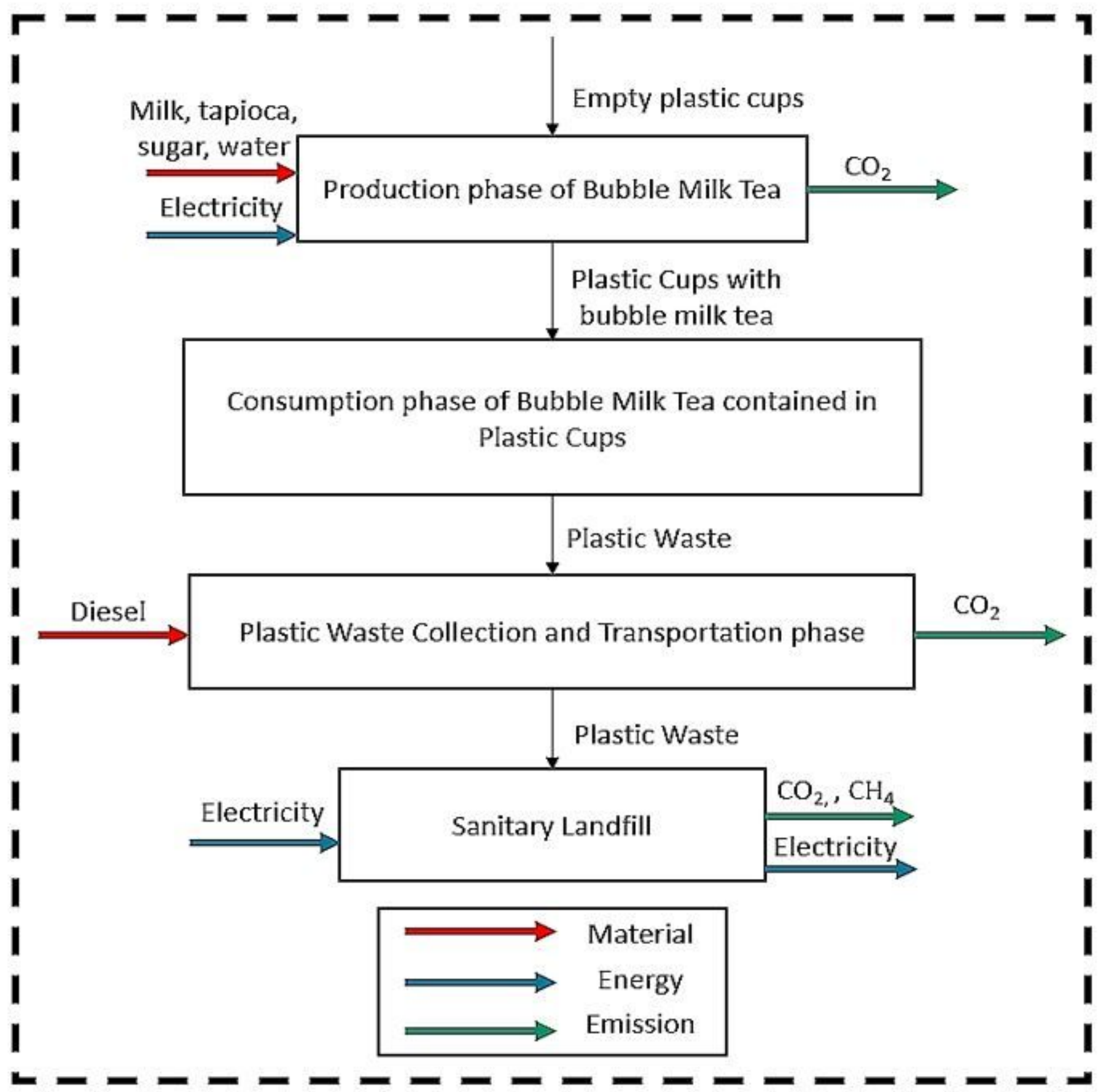

Figure 1

System boundary of existing plastic waste management for Scenario A 


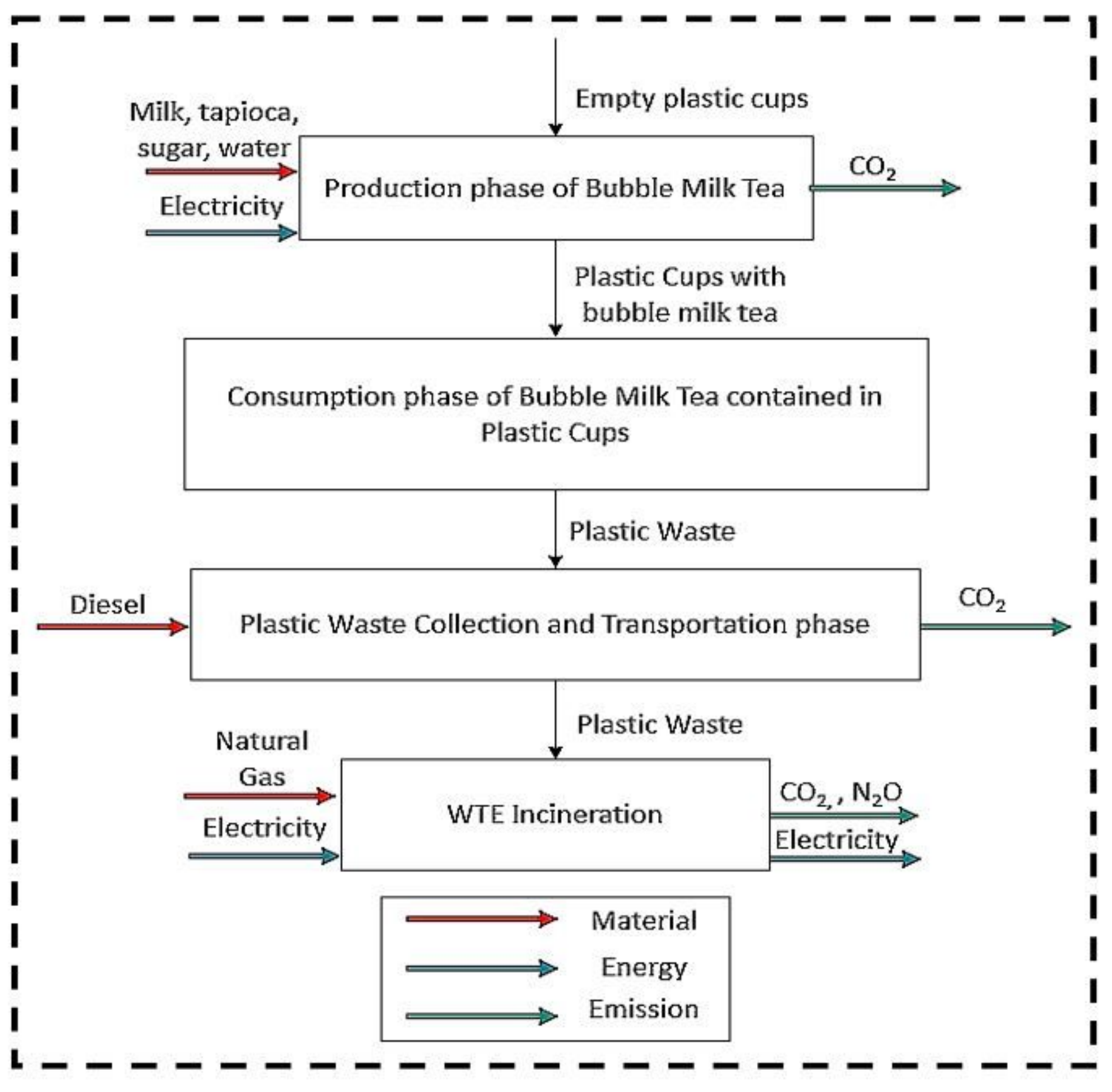

Figure 2

System boundary of plastic waste management for Scenario B 


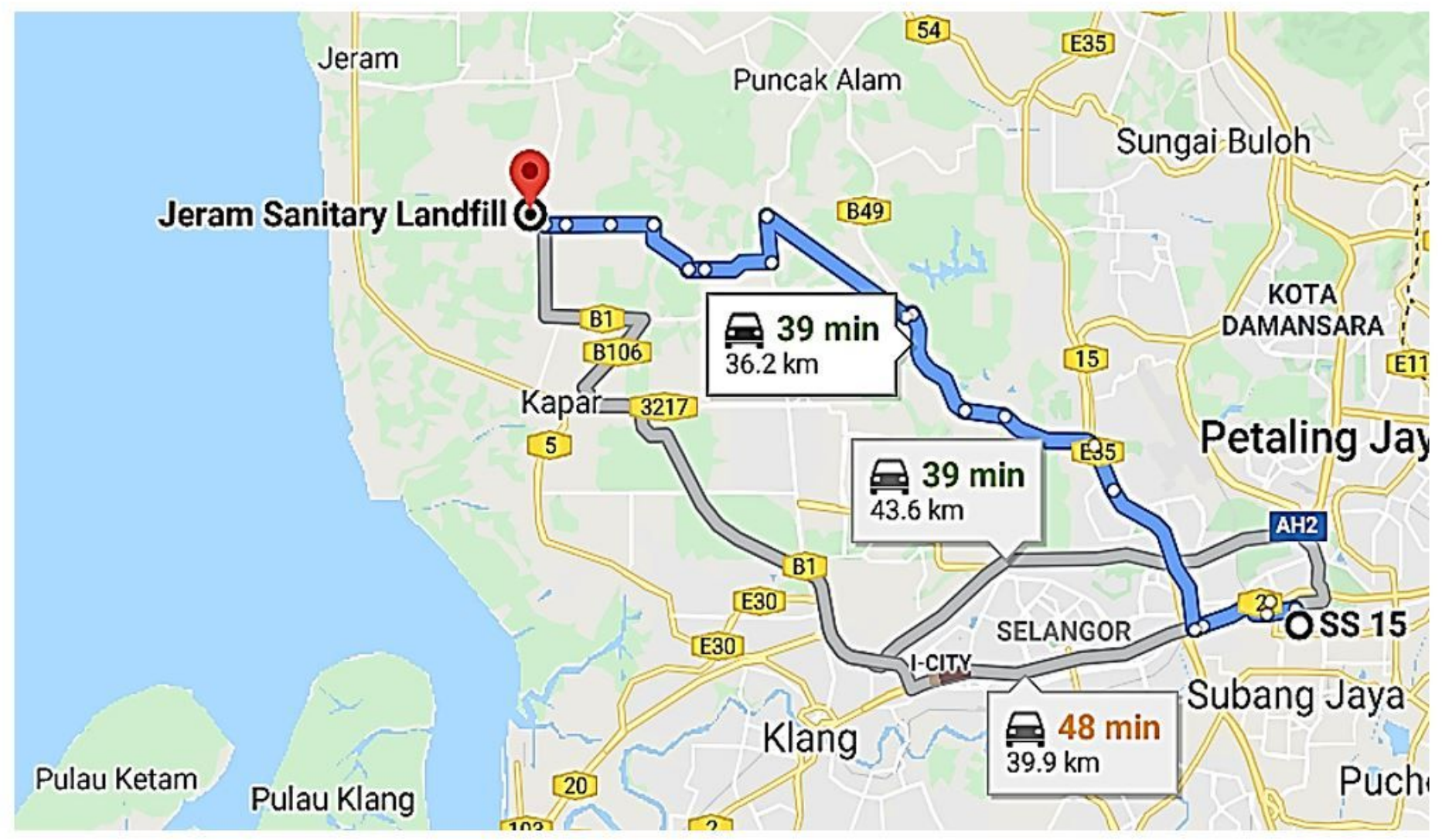

\section{Figure 3}

Map showing travel distance from Subang Jaya to Jeram Sanitary Landfill (Maps, 2020) Note: The designations employed and the presentation of the material on this map do not imply the expression of any opinion whatsoever on the part of Research Square concerning the legal status of any country, territory, city or area or of its authorities, or concerning the delimitation of its frontiers or boundaries. This map has been provided by the authors. 


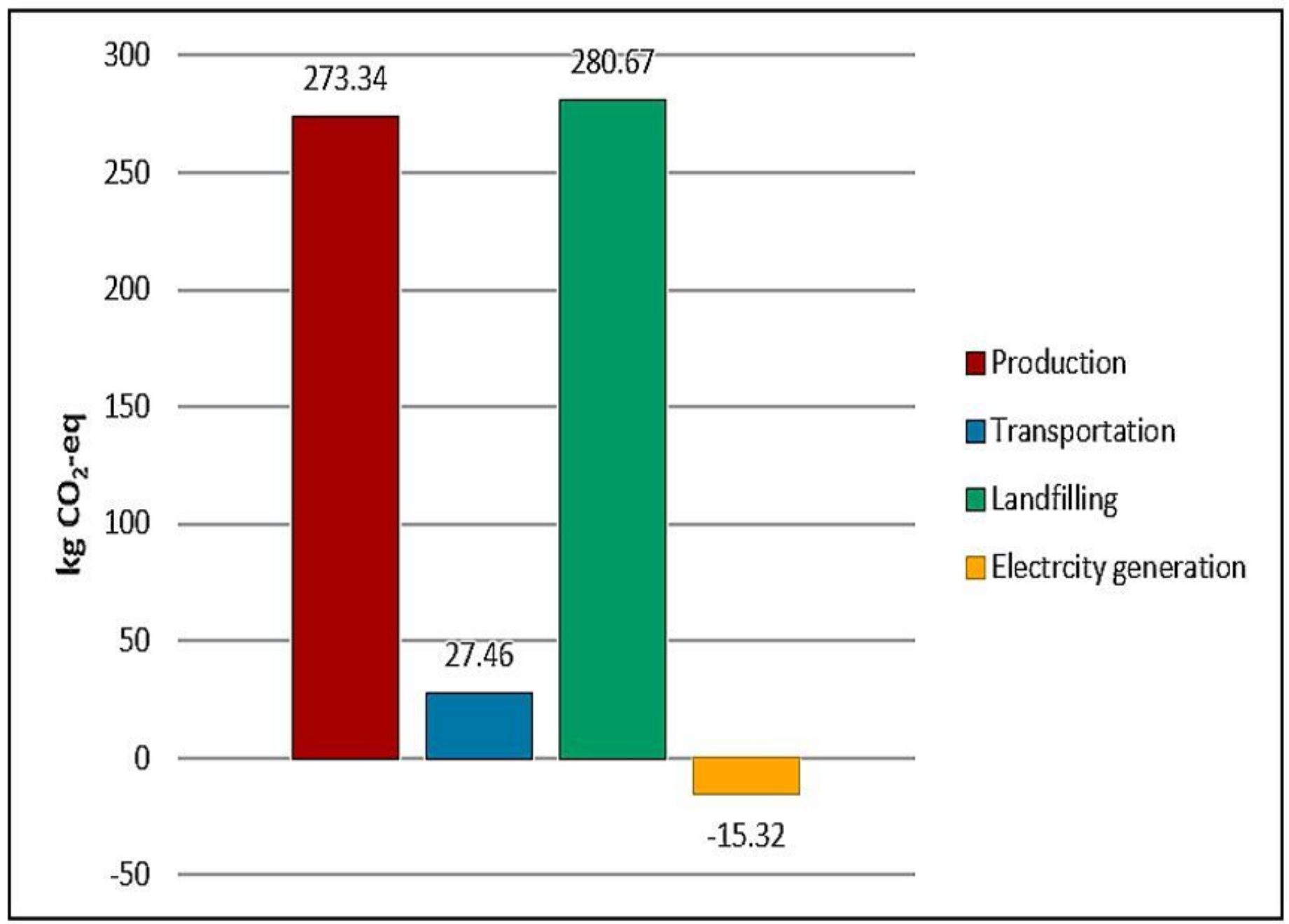

Figure 4

GHG emission of the activities involved in sanitary landfill disposal of 1 tonne of plastic waste for Scenario A 


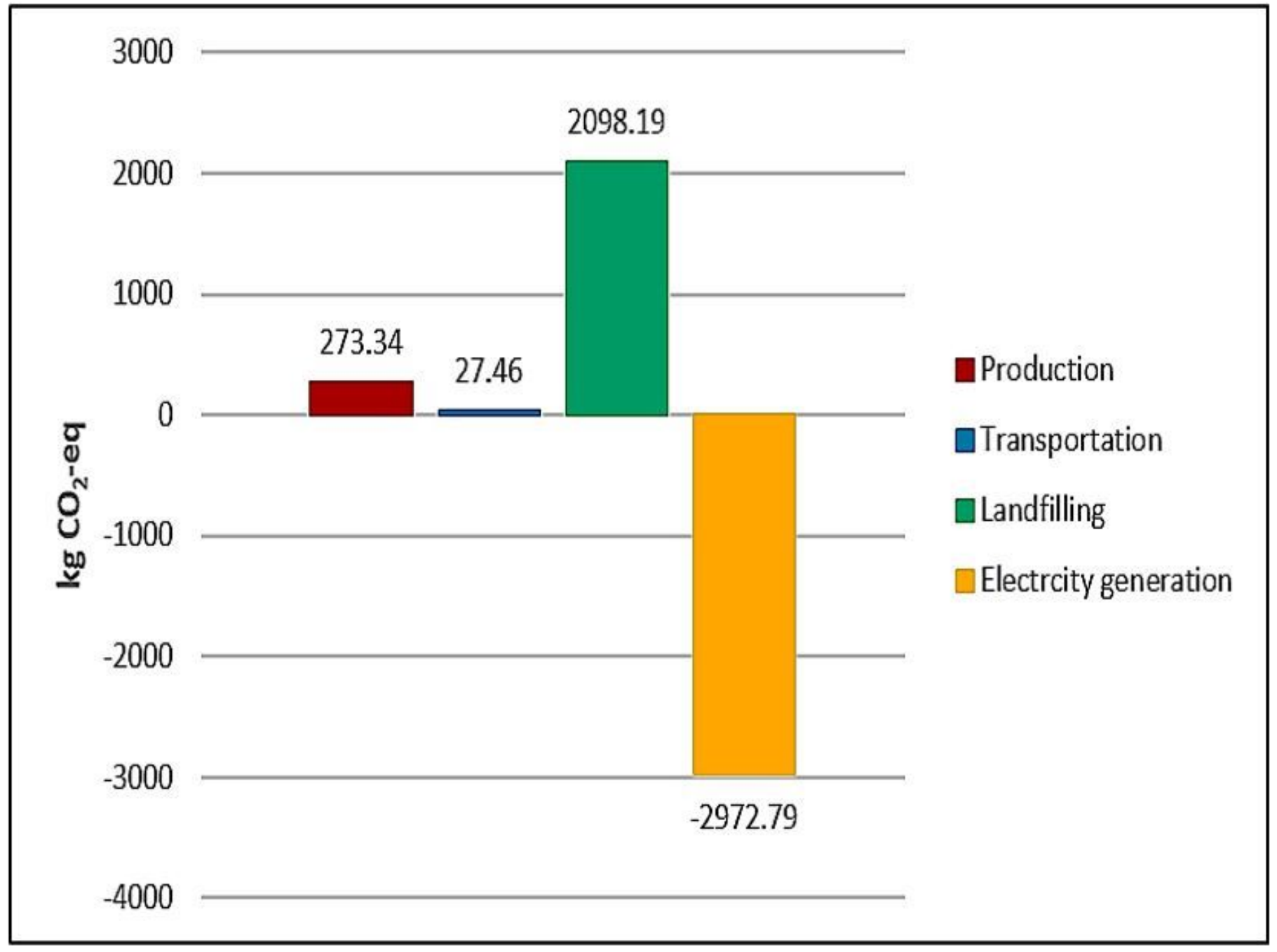

Figure 5

GHG emission of the activities involved in WTE incineration of 1 tonne of plastic waste for Scenario B 


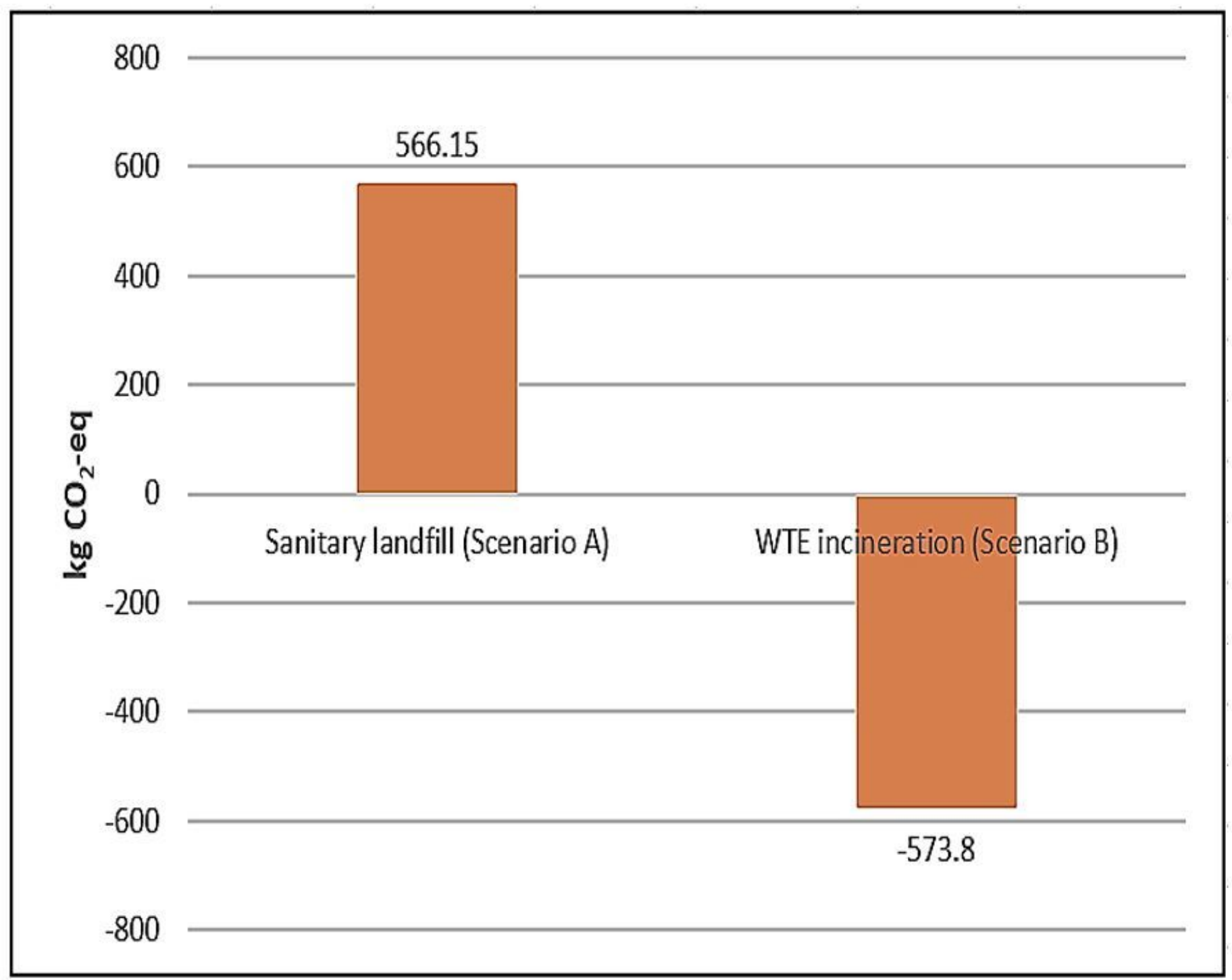

Figure 6

Comparative of net GWP for different plastic waste management scenarios 


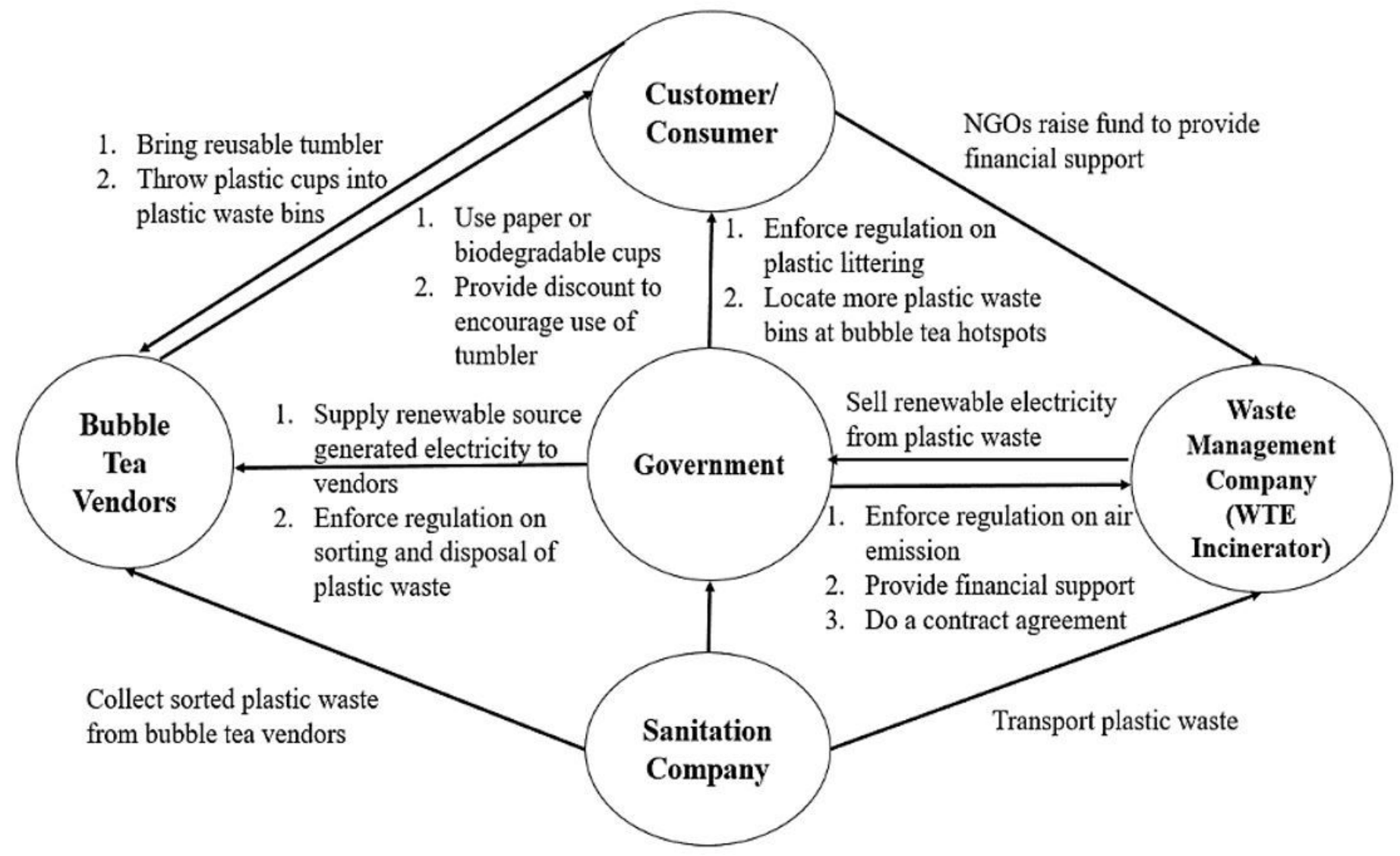

Figure 7

Proposed environmental sustainability framework for plastic waste management in Bubble Tea Streets of Subang Jaya

\section{Supplementary Files}

This is a list of supplementary files associated with this preprint. Click to download.

- GraphicalAbstract.docx 